\title{
PROCEDURE FOR EVALUATING OBSERVATION-WELL NETWORKS IN WYOMING, AND APPLICATION TO NORTHEASTERN WYOMING, 1986
}

By Joe C. Wallace and Marvin A. Crist

U.S. GEOLOGICAL SURVEY

Water-Resources Investigations Report 88-4215

Prepared in cooperation with the

U.S. BUREAU OF LAND MANAGEMENT

and the

WYOMING STATE ENGINEER

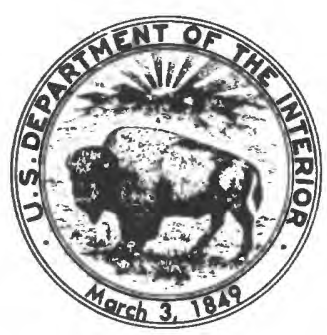

Cheyenne, Wyoming

1989 


\section{DEPARTMENT OF THE INTERIOR MANUAL LUJAN, JR., Secretary U.S. GEOLOGICAL SURVEY \\ Dallas L. Peck, Director}

For additional information contact:

District Chief

U.S. Geological Survey

2617 E. Lincolnway, Suite B

Cheyenne, Wyoming 82001
Copies of this report can be purchased from:

U.S. Geological Survey Books and Open-File Reports Federal Center, Bldg. 810 Box 25425

Denver, Colorado 80225 


\section{CONTENTS}

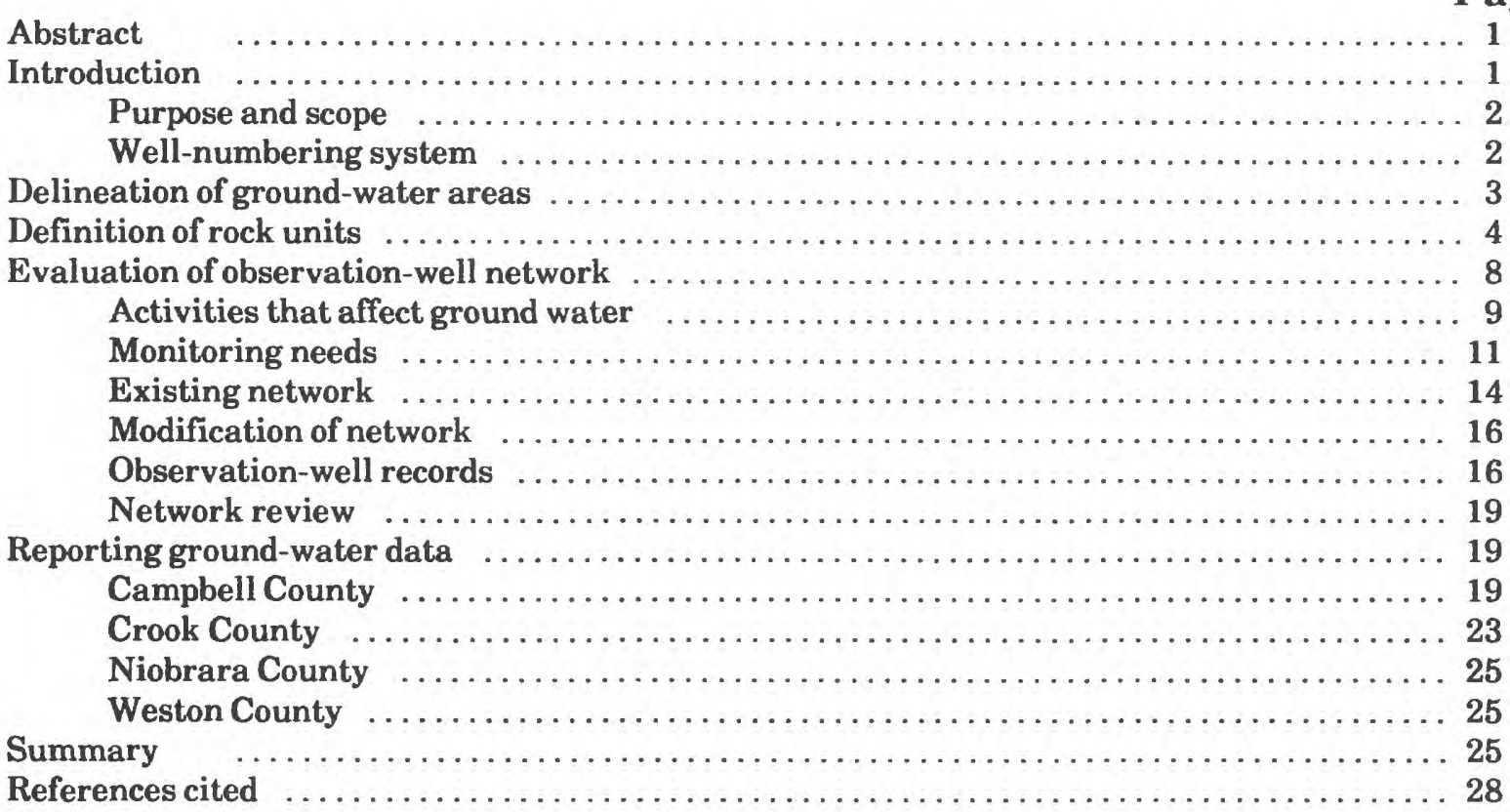

\section{FIGURES}

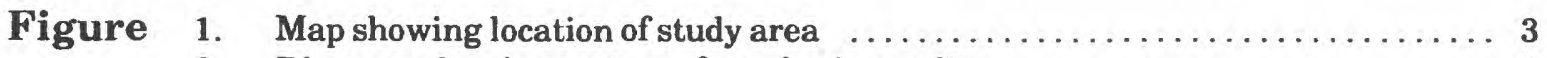

2. Diagram showing system of numbering wells $\ldots \ldots \ldots \ldots \ldots \ldots \ldots \ldots \ldots$

3. Map showing ground-water areas in Wyoming, based on structural features . 5

4. Chart showing rock units based on stratigraphy for the northeastern Wyoming

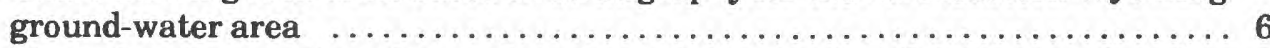

5-7. Maps showing location of ground-water withdrawals for oil-field waterflooding and municipal use from the:

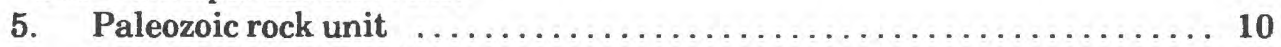

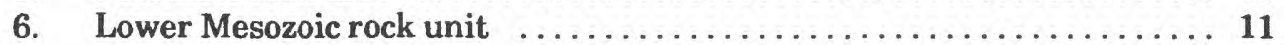

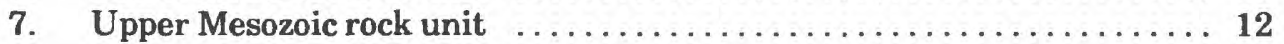

8. Map showing location of ground-water withdrawals from the Tertiary rock unit for oil-field waterflooding, surface coal-mining operations, and

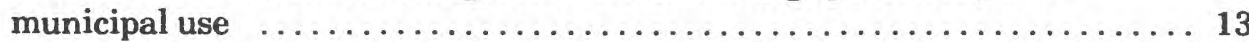

9. Map showing location of observation wells in northeastern Wyoming, 1986 . 15

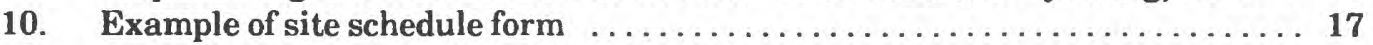

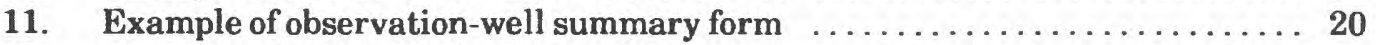

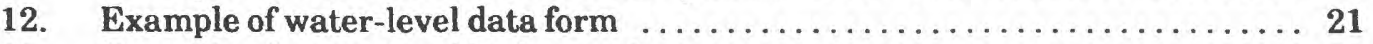

13. Example of water-level hydrograph $\ldots \ldots \ldots \ldots \ldots \ldots \ldots \ldots \ldots \ldots \ldots \ldots \ldots \ldots \ldots \ldots \ldots, 22$

14-17. Location maps and hydrographs of water levels in wells in:

14. Campbell County $\ldots \ldots \ldots \ldots \ldots \ldots \ldots \ldots \ldots \ldots \ldots \ldots \ldots \ldots \ldots \ldots \ldots \ldots \ldots, 23$

15. Crook County $\ldots \ldots \ldots \ldots \ldots \ldots \ldots \ldots \ldots \ldots \ldots \ldots \ldots \ldots \ldots \ldots \ldots \ldots \ldots \ldots \ldots \ldots, 24$

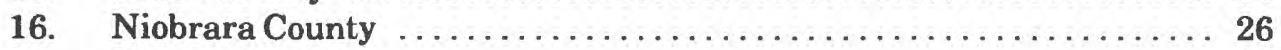

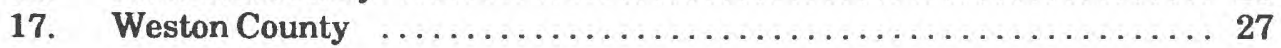




\section{CONVERSION FACTORS}

For use of readers who prefer to use metric (International System) units, conversion factors for inch-pound units used in this report are listed below:

Multiply inch-pound unit

acre

foot

gallon per minute

mile

square mile
By

0.4047

0.3048

0.06308

1.609

2.590
To obtain metric unit

hectare

meter

liter per second

kilometer

square kilometer 


\title{
PROCEDURE FOR EVALUATING OBSERVATION-WELL NETWORKS IN WYOMING, AND APPLICATION TO NORTHEASTERN WYOMING, 1986
}

\author{
By Joe C. Wallace and Marvin A. Crist \\ ABSTRACT
}

A logical sequence of steps was developed for evaluating and modifying the existing, long-term, observation-well network in any part of Wyoming. Monitoring water levels was emphasized, although monitoring water-quality changes also was considered. The State was subdivided geographically into nine ground-water areas, including the northeastern Wyoming ground-water area, based on major structural features. Northeastern Wyoming was the first of the nine areas to be evaluated using these procedures.

The stratigraphic units of Wyoming were grouped into five rock units based on age, similarity of depositional environments, and water-yielding properties. These units, from oldest to youngest, are: (1) Paleozoic rock unit, (2) lower Mesozoic rock unit, (3) upper Mesozoic rock unit, (4) Tertiary rock unit, and (5) Quaternary rock unit.

On the basis of an evaluation of activities likely to affect ground water in northeastern Wyoming, the most important monitoring needs in the area are related to: (1) Oil-field waterflooding, (2) surface mining of coal, (3) increasing municipal use of ground water, and (4) need for general resource information. The 18 observation wells in the existing (1986) network meet most of the needs identified. Seven additional wells need to be added to the network, whereas four wells in the network can be discontinued.

Water-level data from the 18 observation wells in northeastern Wyoming are presented in a format somewhat different from that used in previous data reports for Wyoming. For each county, hydrographs of water levels are arranged adjacent to a map showing the location of the wells. An accompanying narrative includes discussion of changes in water levels, water quality, changes in water use, possible changes in hydrologic conditions, or other information pertinent to the records obtained.

As of 1986, substantial water-level declines were recorded in one well completed in the fort Union Formation of Paleocene age near Gillette, in one well completed in the Lance Formation and Fox Hills Sandstone of Late Cretaceous age near Gillette, and in one well completed in the Lakota Formation of Early Cretaceous age in northern Niobrara County. Substantial water-level rises were recorded in one well completed in the Wasatch Formation of Eocene age at Gillette and in one well completed in the Madison Limestone of Mississippian age in northern Niobrara County.

\section{INTRODUCTION}

The U.S. Bureau of Land Management and some State and local agencies are concerned about changes in water levels and water quality that may result from increased use of ground water in northeastern Wyoming. Because of the rapid rate of development of coal and other energy minerals in the area during the past $\mathbf{1 5}$ years, the use of ground water has changed in many places from agricultural to a combination of agricultural, municipal, and industrial. Of particular concern are areas near surface coal mines, in and near oil fields, and near the city of Gillette. Observation wells are used throughout Wyoming to monitor the effects of economic development on ground water, as well as to assess and monitor the natural occurrence of ground water in areas not affected by human activity.

During 1983-86, the U.S. Bureau of Land Management sponsored a study in which the U.S. Geological Survey evaluated the observation-well network in northeastern Wyoming. Although the 
study was intended to provide information needed by the Bureau of Land Management, it was directly related to the cooperative water-resources investigations program of the Geological Survey and Wyoming State Engineer.

The observation-well network in northeastern Wyoming is part of a statewide network operated cooperatively by the Geological Survey and the State Engineer since the 1940's. In recent years, the Wyoming Economic Development and Stabilization Board also has supported the monitoring program, which generally serves the needs of other agencies as well. All data used in the evaluation were obtained through that program, which includes more than 80 observation wells, statewide. In a separate but related activity, the Geological Survey annually collects water-quality samples from a few selected wells, in cooperation with the Wyoming Department of Agriculture.

The study area (fig. 1) is about 18,200 square miles of northeastern Wyoming, including most of the Powder River structural basin, that part of the Black Hills uplift in Wyoming, and the area between those structural features. Throughout most of this semiarid area, surface water is not available, so ground water is used. A general overview of the land, resources, and hydrology of the area is given in the report of Lowry, Wilson and others (1986). The ground-water hydrology is described by Hodson and others (1973).

\section{Purpose and Scope}

The purpose of this report is to describe the results of the two-part study: (1) Development of a logical sequence of steps for evaluating and, if necessary, modifying the long-term, observation-well network in any part of Wyoming; and (2) application of those steps to the network in northeastern Wyoming. Water-level monitoring is emphasized; water-quality monitoring is part of other ongoing investigations. Whether modifications indicated for northeastern Wyoming should be implemented or the procedures applied to other areas of the State will be determined later, in consultation with the State Engineer and any other interested agencies, such as the Bureau of Land Management. Regardless of those decisions, however, the modified format proposed in this report for reporting observation-well information should be useful for the statewide monitoring program.

To a large extent, the procedures documented in this report are the same as, or similar to, the less formal procedures already in use. Annually, Geological Survey and State Engineer personnel meet to assess the observation-well program. The information obtained from each well is evaluated, together with changing priorities for information throughout the State. Wells are eliminated from the program and new ones added, within the constraints of available funding and personnel.

For this evaluation, consideration was given only to observation wells used for long-term monitoring of water levels (longer than 3 years). During many geohydrologic studies of specific areas, data are collected from a large number of short-term observation wells--commonly for 2 to 3 years. At the end of each study, the wells used in the study are evaluated for possible addition to the long-term monitoring program.

\section{Well-Numbering System}

Wells cited in this report are numbered by a method based on the U.S. Bureau of Land Management system of land subdivision in Wyoming (fig. 2). The first number indicates the township, the second the range, and the third the section in which the well is located. Letters following the section number indicate the location of the well within the section. The first letter denotes the quarter section, the second letter the quarter-quarter section, and the third letter the quarter-quarter-quarter section (10acre tract). The subdivisions of a section are designated A, B, C, and D in a counterclock wise direction, beginning with the northeast quarter. Wells listed in a 10-acre tract are numbered consecutively beginning with 01 following the letters of the well number. If a section is not 1 square mile, it is 


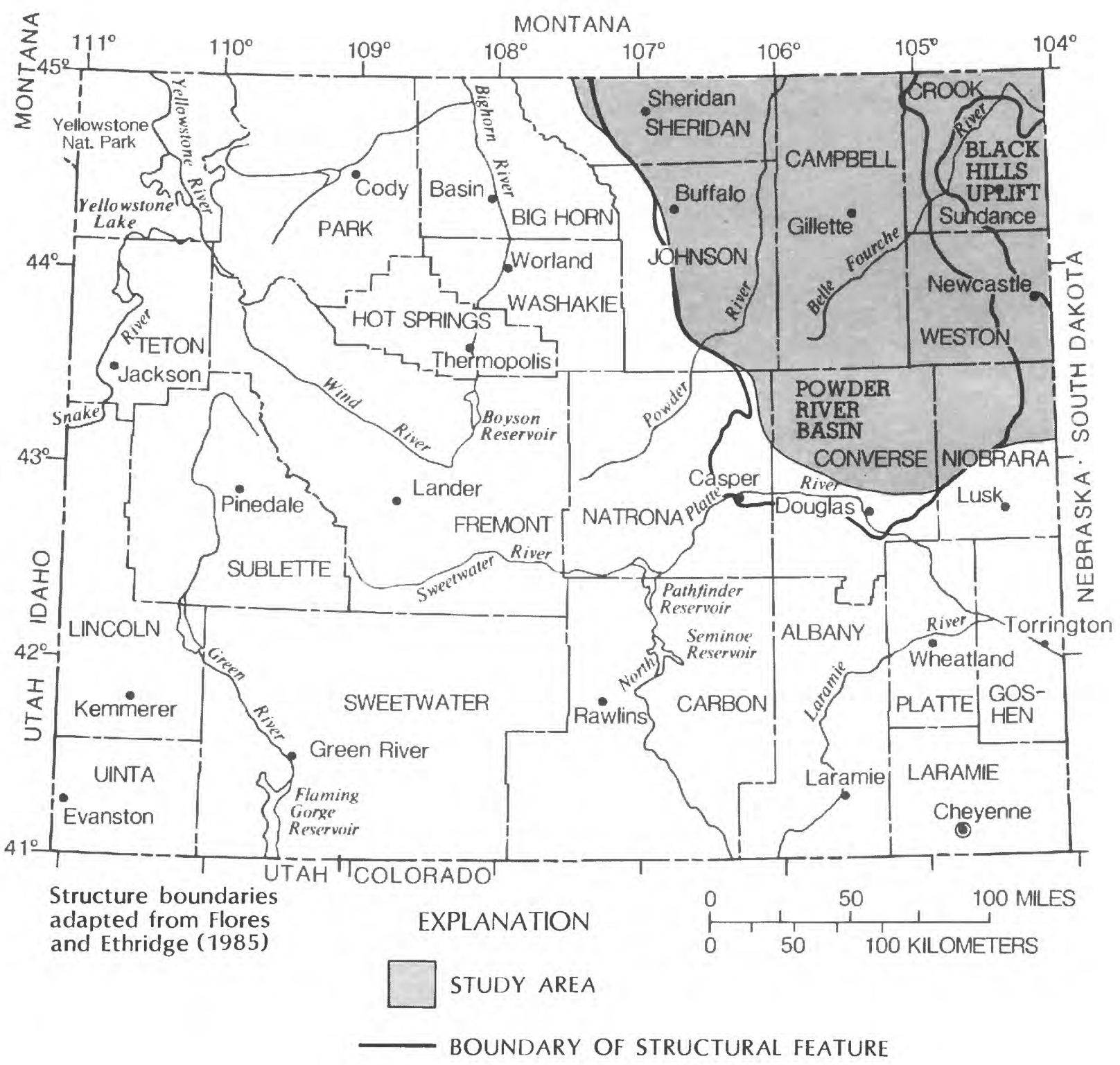

Figure 1.--Location of study area.

treated as a full section with the southeast section corner serving as the reference point for the subdivision of the section.

\section{DELINEATION OF GROUND-WATER AREAS}

The first step in this study was to delineate nine ground-water areas in the nonmountainous areas of Wyoming (fig. 3), because evaluation of observation-well networks is most convenient when performed on only one part of the State at a time. Because geologic structure, to some degree, limits ground-water movement, boundaries of the ground-water areas were based on major structural features, principally basins and uplifts described by Love (1961). The ground-water system within each area generally can be considered to be independent of the ground-water system in other areas. Some designated ground-water areas include more than one structural basin or include land adjacent to the named structural basin, either because the geologic formations are similar throughout the ground-water area or because of possible hydrologic connection across structural boundaries. Northeastern Wyoming (area 1, fig. 3) is the first of the nine ground-water areas to be evaluated using the procedures described in this report. 


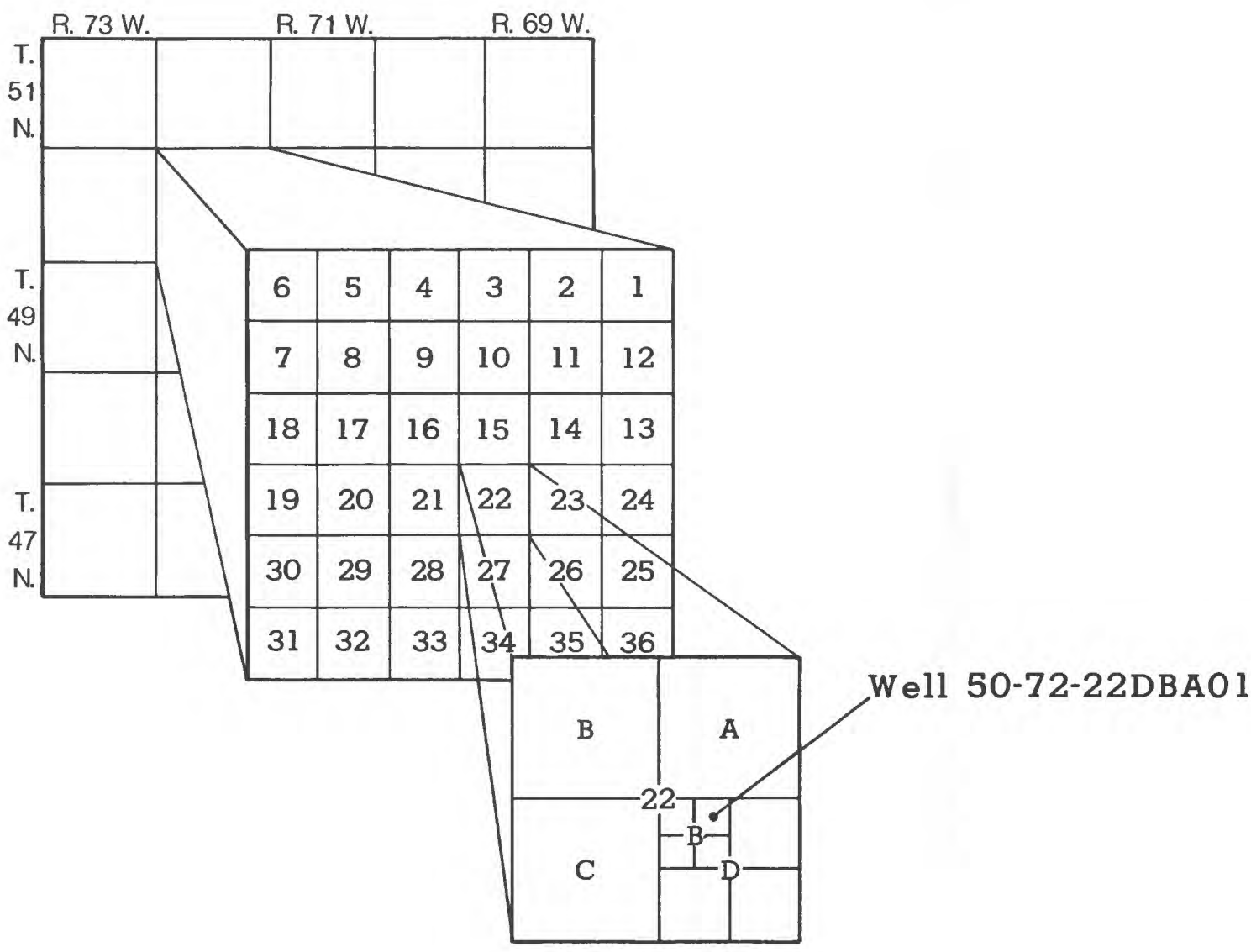

Figure 2.--System of numbering wells.

\section{DEFINITION OF ROCK UNITS}

In order to generalize the relation between geologic formations and the use of ground water, the stratigraphic units of Wyoming were divided into five rock units based on age, similarity of depositional environments, and water-yielding properties, as reported by Crist and Lowry (1972, p. 44). The names of equivalent formations commonly are different in different parts of the State, highlighting the need to group formations into equivalent units having the same name statewide. The aggregated units are useful for general characterization of ground water in one ground-water area, or for comparing hydrologic information for one area with that of another. Such aggregation is especially useful where the density of observation wells is as sparse as it is in both northeastern Wyoming and the entire State--about one well per 1,000 square miles. The combining of units, however, is not intended to preclude monitoring specific aquifers as needed.

In northeastern Wyoming, exposed bedrock units range from Precambrian crystalline rocks to upper Tertiary sedimentary rocks. Unconsolidated Quaternary deposits are present in many stream valleys. The bedrock units delineate the major structures of the area--mountain uplifts and a large synclinal basin. Precambrian rocks are exposed in the cores of the uplifts, and progressively younger rocks through Cretaceous age outline the uplifts and the basin. Widespread deposits of nearly flatlying lower Tertiary rocks mantle the center of the structural basin.

The rock units and stratigraphy for northeastern Wyoming are diagrammed in figure 4 . Equivalent rock units for the other eight ground-water areas in Wyoming may be determined by examination of the latest stratigraphic nomenclature chart for Wyoming; for this study, the chart prepared by Love and others (1987) was used. The formations used for the upper and lower limits of the rock units in other ground-water areas of Wyoming may be determined when the observation-well networks in the other areas are evaluated. Igneous and metamorphic rocks of Precambrian age were excluded from this classification. 


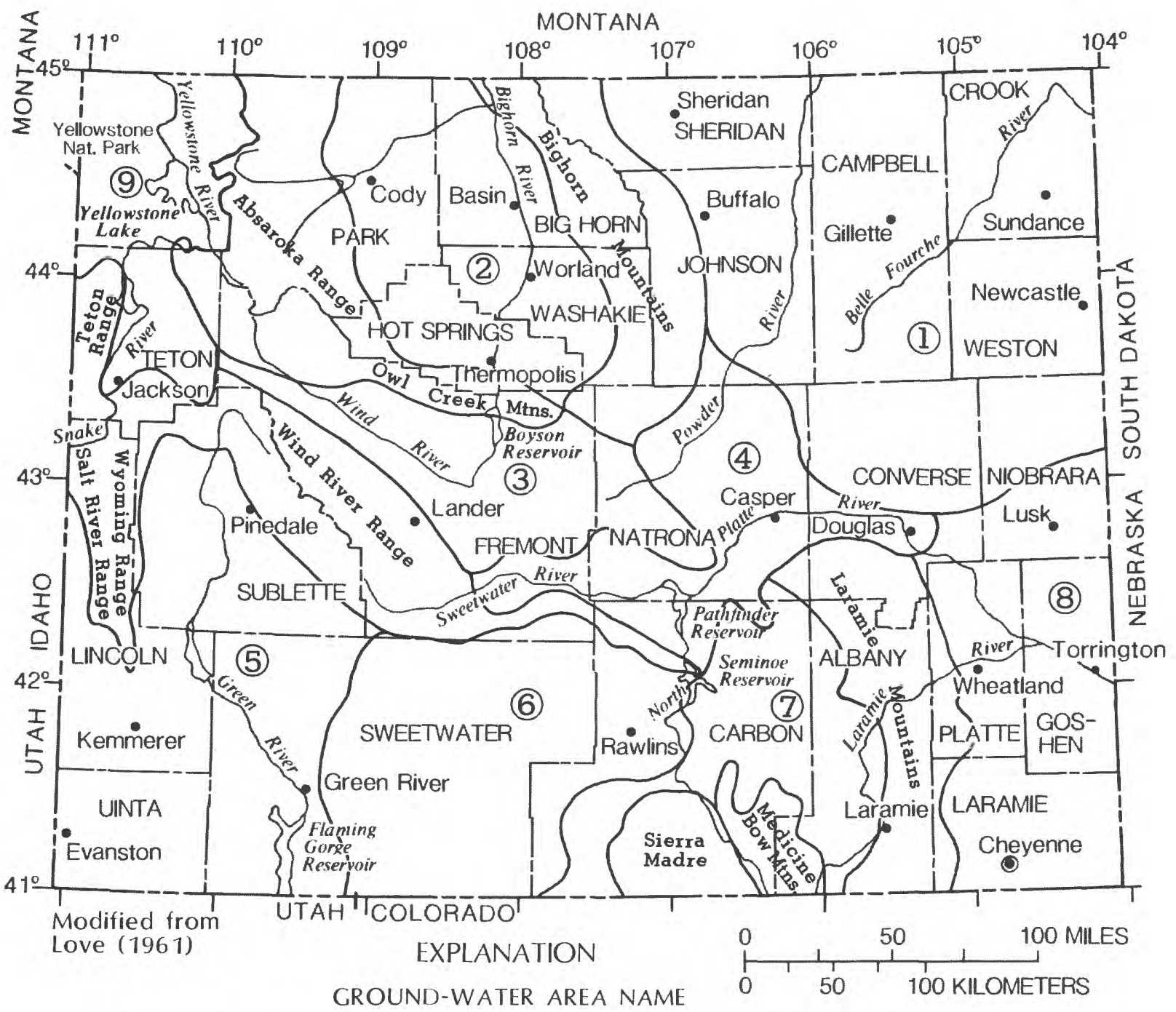
(1) Northeastern Wyoming
(6) Great Divide and Washakie basins
(2) Bighorn Basin
(3) Wind River basin
(7) Laramie, Hanna, and Shirley basins
(4) Central Wyoming
(8) Southeastern Wyoming
(5) Southwestern Wyoming
(9) Northwestern Wyoming

Figure 3.--Ground-water areas in Wyoming, based on structural features.

The rock units, from oldest to youngest, are:

1. Paleozoic rock unit--Sandstone, siltstone, gypsum, massive limestone, massive dolomite, and fossiliferous dolomite comprise formations in this unit. All formations of Paleozoic age are included in this unit. In northeastern Wyoming the principal aquifers in the Paleozoic rock unit are the Madison Limestone and equivalent Pahasapa Limestone of Mississippian age, the Minnelusa Formation of Pennsylvanian and Early Permian age, and the Minnekahta Limestone of Permian age. According to Lowry, Wilson and others (1986, p. 90-91), these formations have potential for large supplies of water--"Fractures and solution openings yield as much as several thousands of gallons per minute to wells. However, yields of only several tens of gallons are common." (Note: Many of the observation wells listed in this report as being completed in the Madison Limestone are in locations where the chart in figure 4 indicates the equivalent Pahasapa Limestone is present. The formation for these wells was reported in completion records and drillers logs as the Madison Limestone.) 


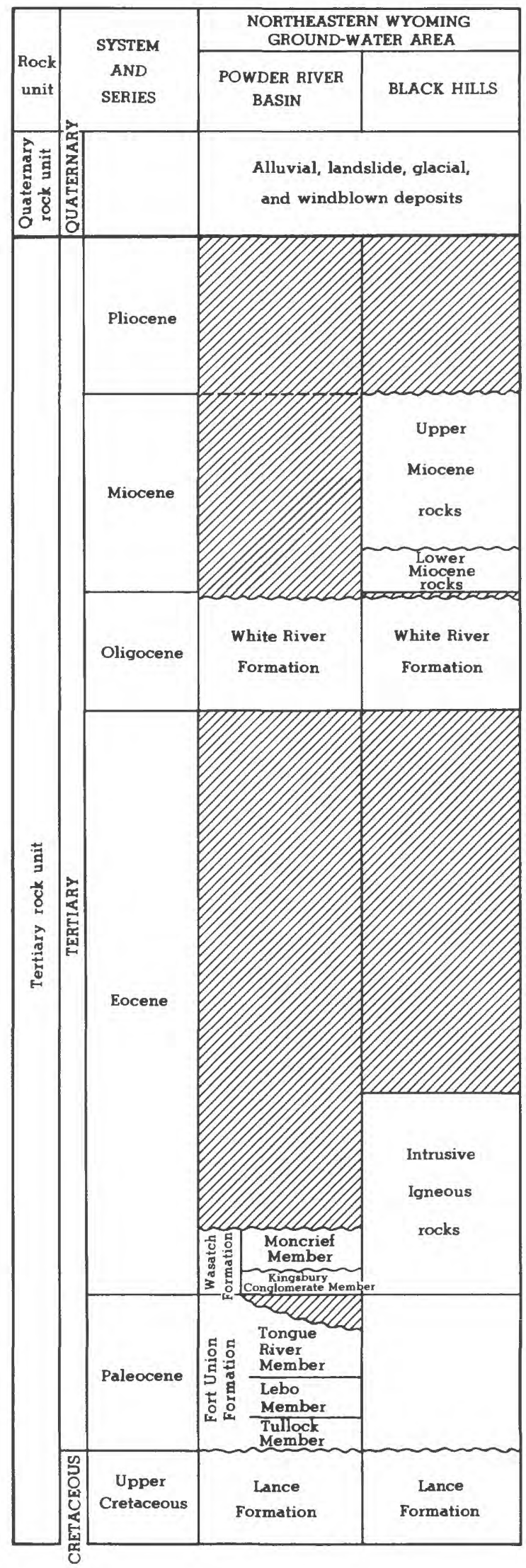

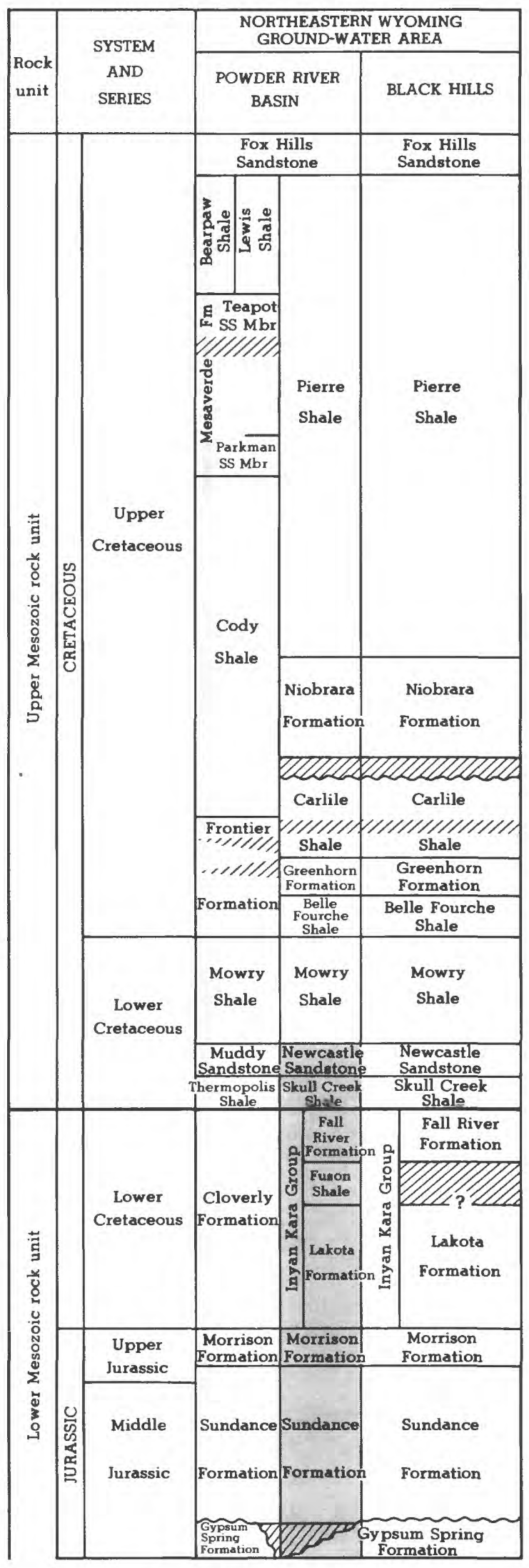

Figure 4.--Rock units based on stratigraphy for the northeastern Wyoming ground-water area. 


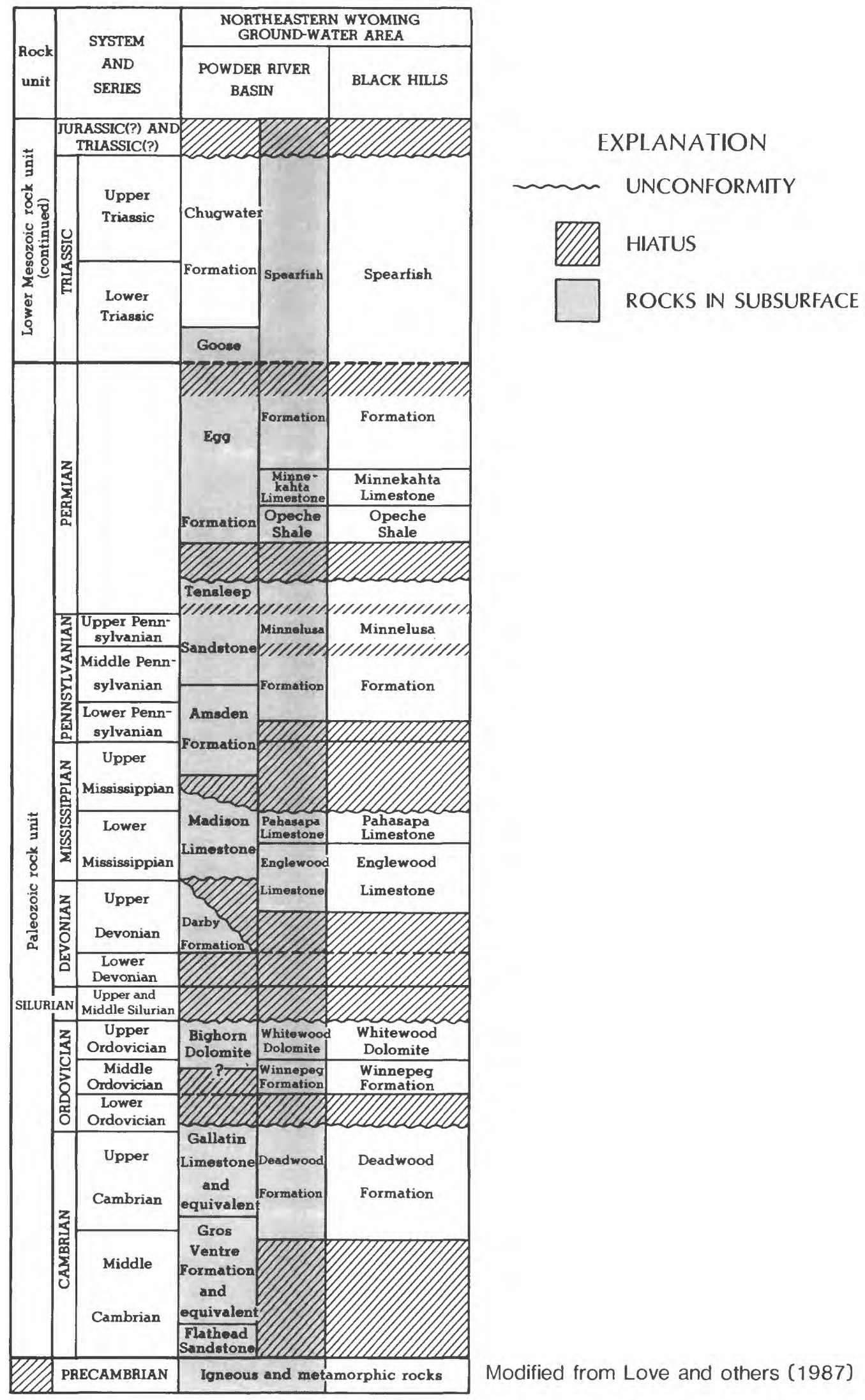

Figure 4.--Rock units based on stratigraphy for the northeastern Wyoming ground-water area--Continued. 
2. Lower Mesozoic rock unit--The formations in this unit, ranging from Triassic age to Early Cretaceous age, consist of variegated bentonitic claystone, variegated siliceous claystone, limestone, sandstone, glauconitic and nonglauconitic shale and sandstone, shale, dolomite, and gypsum. In northeastern Wyoming, the principal aquifer is referred to locally as the Lakota Formation, which is part of the Inyan Kara Group of Early Cretaceous age. Sometimes the subsurface unit locally known as the "Dakota silt" of Early Cretaceous age is included with the Lakota as the source of water to wells. Yields to wells generally are less than 50 gallons per minute; springs and flowing wells that discharge less than 25 gallons per minute are common (Lowry, Wilson and others, 1986, p. 90-91).

3. Upper Mesozoic rock unit--This unit includes formations of Early and Late Cretaceous age that were deposited during a period of general advance and retreat of the seas. These formations consist of marine shale, concretionary marine shale, numerous bentonite beds, limestone, marl, concretionary shale, siliceous shale, and coal. In northeastern Wyoming, most of the water wells in this unit are completed in the Fox Hills Sandstone of Late Cretaceous age. The Fox Hills, of marine origin, is included in this unit, even though it commonly is difficult to distinguish from the overlying Lance Formation of Late Cretaceous age. The Lance is a continental deposit that is included with the Tertiary rock unit. Except for the Fox Hills Sandstone, there is little potential for developing water supplies from this unit (Lowry, Wilson and others, 1986, p. 90-91).

4. Tertiary rock unit--This unit includes formations of Late Cretaceous and Tertiary age that were deposited in lakes, lagoons, and sluggish streams. These formations consist of alternating beds of sandstone, siltstone, shale, carbonaceous shale, and coal; shale is the dominant rock type. In northeastern Wyoming, the principal aquifers in the Tertiary rock unit are the Lance Formation of Late Cretaceous age, the Fort Union Formation of Paleocene age, and the Wasatch Formation of Eocene age. Yields of 10 to 20 gallons per minute can be obtained from wells in coal beds or the numerous sandstone lenses; yields of several hundreds of gallons per minute are possible from deeper wells (Lowry, Wilson and others, 1986, p. 9091).

5. Quaternary rock unit--This unit includes alluvial, landslide, glacial, and windblown deposits of Quaternary age. There are no major aquifers in this unit in northeastern Wyoming, although small supplies for stock watering or irrigation are withdrawn from alluvium along a few of the larger streams in the area.

\section{EVALUATION OF OBSERVATION-WELL NETWORK}

During this study, a logical sequence of eight steps was developed for evaluating and, if necessary, modifying an observation-well network in Wyoming. The first two steps are done only once:

1. Delineation of ground-water areas.

2. Definition of rock units.

The remaining six steps are for use during periodic evaluations of the network in a given groundwater area. These steps, listed below, were applied to the network in northeastern Wyoming in this study and are discussed in detail in subsequent sections of this report:

3. Summarize the resource-development and water-use activities that could affect ground water.

4. Determine needs for monitoring, based on step 3. 
5. Compare needs (from step 4) with the existing observation-well network. Determine deficiencies in fulfilling identified monitoring needs; identify wells no longer needed, if any.

6. Identify and visit wells that can be added to the network to fulfill monitoring needs.

7. Set up a record file for each observation well.

8. Review the network periodically.

\section{Activities That Affect Ground Water}

As previously mentioned, the general purpose of an observation well usually is to monitor either the natural occurrence of ground water or the effects of human activities on ground-water quantity or quality. Once a ground-water area has been selected for network evaluation, the next step is to inventory the human activities (resource development or water use or both) in the area, as a basis for determining where observation wells might be needed. A few of the activities that might affect ground water are: Manufacturing or processing, surface mining of coal or uranium, irrigation, oil production, construction of dams or canals, changes in stream channels, changes in land use, and increase or decrease of urban population. Information for the inventory usually is available from other government agencies and in published reports.

The activities most likely to affect ground-water quantity or quality in northeastern Wyoming were grouped into three categories: (1) Agricultural and rural-domestic use, (2) use for oil and gas production and coal and uranium mining, and (3) use for municipal and other public water supplies. Agricultural withdrawals for irrigation and stock watering comprise the largest use of fresh ground water; however, since about 1967, there has been a substantial increase in use of ground water by the energy-minerals industry. If water withdrawn as a by-product of oil production is included, the oil industry withdraws the largest quantity of ground water (Feathers and others, 1981, p. 30-48).

Wells used for agricultural and rural-domestic supplies commonly are completed in the shallowest aquifer that will supply the desired yields. These wells generally yield less than 25 gallons per minute and are usually located so that pumping of one well does not affect any other well. Feathers and others $(1981$, p. 48) estimated that the largest quantity of ground water is used for stock watering; however, they assumed that all such supplies were from ground water and disregarded surface-water supplies, such as streams and stock ponds. To date (1986), there has not been extensive use of ground water for irrigation in the northeastern Wyoming ground-water area. Because agricultural and rural-domestic withdrawals probably have only small, local effects on ground-water levels in this area, no further consideration was given to monitoring that category.

Most of the ground water withdrawn for industrial use in northeastern Wyoming is for secondary recovery of oil (referred to in this report as "oil-field waterflooding"). Osborne and others (1962, p. 1) define waterflooding as ". . a secondary-recovery method in which water is injected into a reservoir to obtain additional oil recovery by movement of reservoir oil to a producing well after the reservoir has approached its economic productive limit by primary-recovery methods." Water from four of the five rock units is used for oil-field waterflooding, mainly in Campbell, Crook, and Weston Counties.

The use of ground water for mining and related activities increased substantially between 1970 and about 1980. Although most of the uranium industry currently (1986) is inactive, surface mining of coal increases almost every year; Campbell County leads the United States in coal production. The cumulative effects of 16 existing and 6 planned surface coal mines on ground-water quantity and quality in the Tertiary rock unit is described by Martin and others (1988). 
As urban populations expanded after 1970 as a result of energy-minerals exploration and development (particularly in Campbell County), municipalities expanded water-supply facilities and developed new sources of water. Because of meager surface-water supplies throughout most of the study area and legal constraints on use of surface water, municipal use of ground water has increased substantially. Withdrawals for municipal use and public supply mainly are from the Paleozoic rock unit and the Tertiary rock unit in Campbell, Crook, and Weston Counties.

The results of assessing human activities that might affect ground water in northeastern Wyoming are illustrated on the maps shown in figures 5 through 8 . The location of areas of withdrawals of ground water for oil-field waterflooding and for municipal use are shown in figure 5 for the Paleozoic rock unit, figure 6 for the lower Mesozoic rock unit, figure 7 for the upper Mesozoic rock unit, and figure 8 for the Tertiary rock unit. Areas of ground-water withdrawals for coal mining also are shown in figure 8. The principal aquifers were listed in the preceding discussion of the rock units.

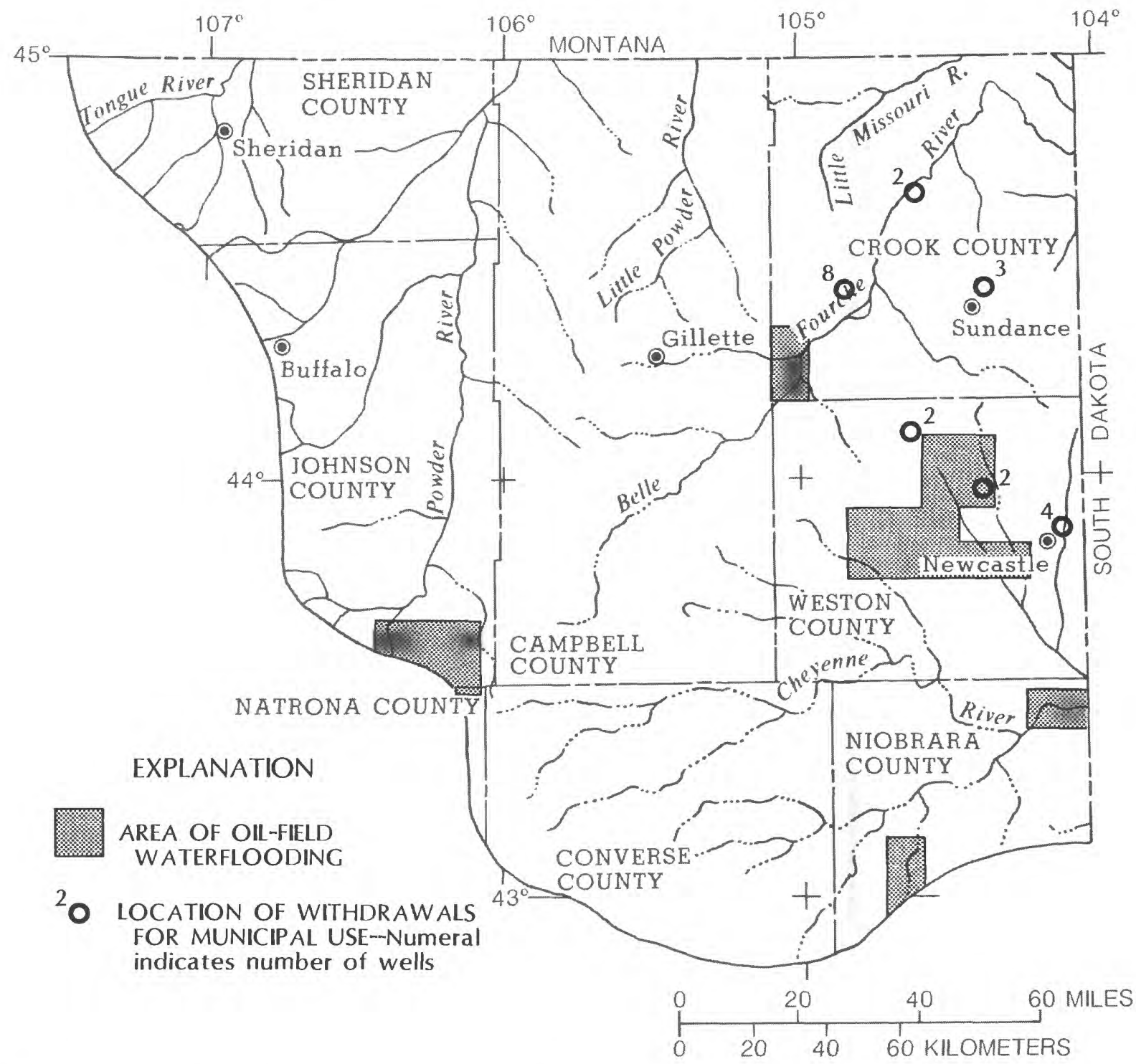

Figure 5.--Location of ground-water withdrawals from the Paleozoic rock unit for oil-field waterflooding and municipal use. (Data modified from Wyoming Oil and Gas Conservation Commission, 1982, and Feathers and others, 1981.) 


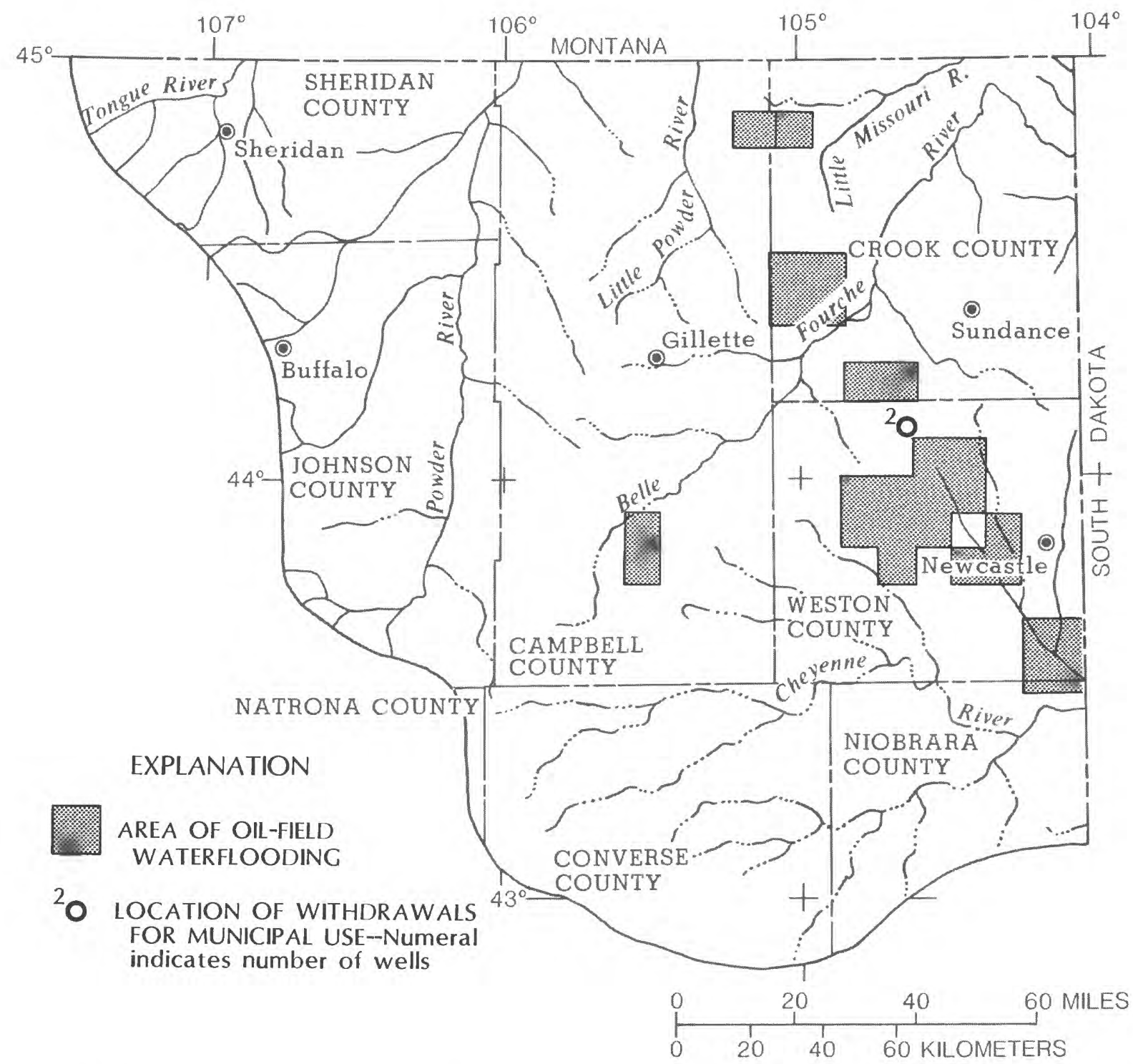

Figure 6.--Location of ground-water withdrawals from the lower Mesozoic rock unit for oil-field waterflooding and municipal use. (Data modified from Wyoming Oil and Gas Conservation Commission, 1982, and Feathers and others, 1981.)

\section{Monitoring Needs}

The previously discussed information about human activities that may affect ground-water resources in a given ground-water area can be used to decide where observation wells are needed. Also, after completion of a hydrologic study related to effects of resource development on ground water, consideration usually is given to adding one or more wells used in the study to the network. Waterwell data, including location, depth, formation, and withdrawals, are helpful when assessing monitoring needs. Consideration also needs to be given to monitoring where ground water at present is not affected by human activity. For natural areas, more subjective criteria are used, such as anticipated future development that will use or affect ground water, or the lack of water-resources information for a certain aquifer.

Monitoring needs for the northeastern Wyoming ground-water area were determined mainly by considering: (1) Oil-field waterflooding, (2) surface mining of coal, (3) increasing municipal use, and (4) need for general resource information. In the following discussion of monitoring needs by rock unit, existing observation wells are not mentioned; in fact, most of the observation wells judged in this study to be needed in northeastern Wyoming already are in the network. The relations of these wells to monitoring needs are described in a subsequent section on the existing network. 


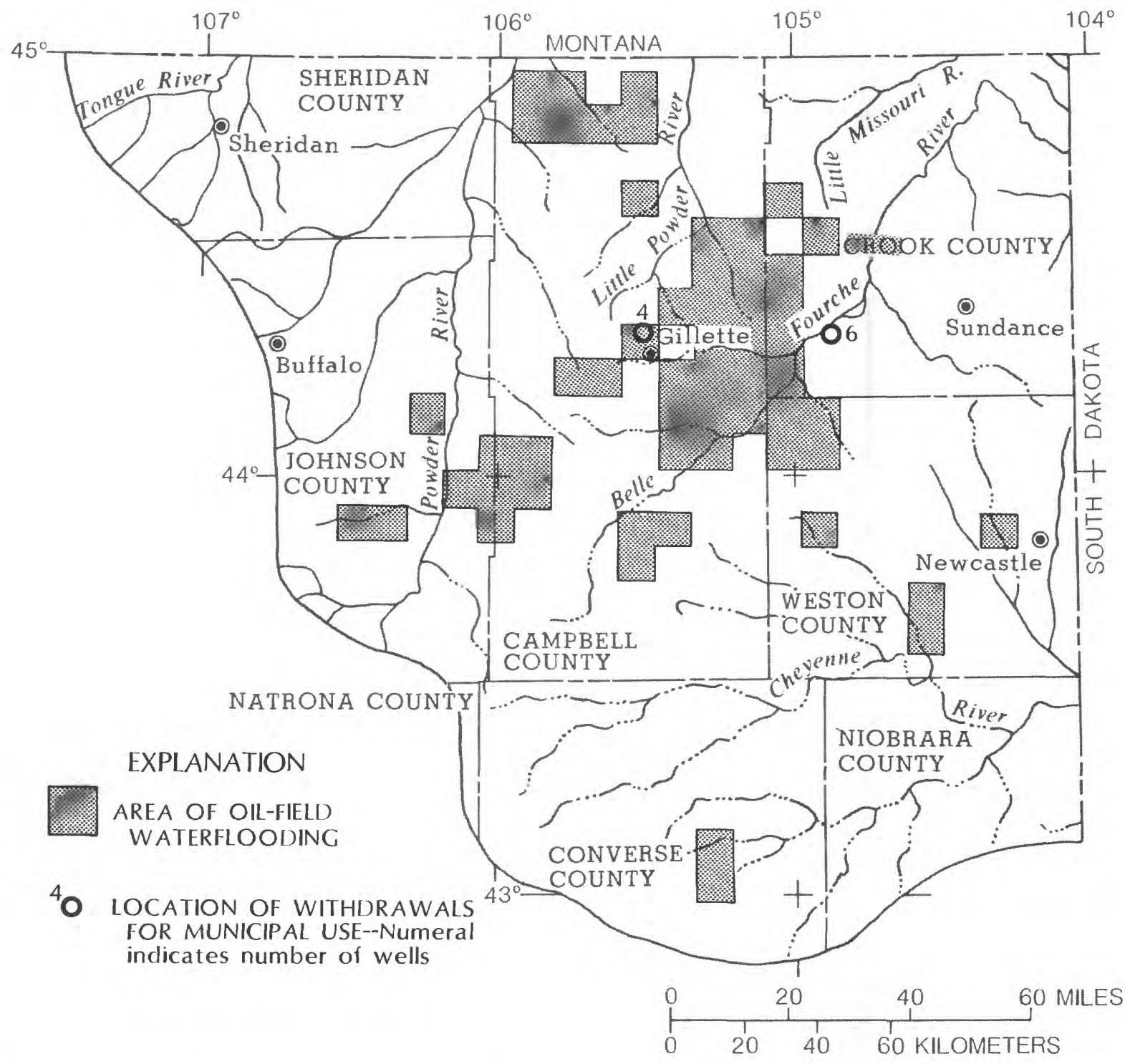

Figure 7.--Location of ground-water withdrawals from the upper Mesozoic rock unit for oil-field waterflooding and municipal use. (Waterflood data from Wyoming Oil and Gas Conservation Commission, 1982.)

In the Paleozoic rock unit, water from the Madison Limestone is used mainly for oil-field waterflooding and for several municipal supplies (fig. 5). Because large quantities of water may be available from the Madison, it is an aquifer that has been and needs to be monitored for general resource information. Water levels in the Madison need to be monitored in the vicinity of pumpage for oil-field waterflooding in central Weston County, near the concentration of eight wells in western Crook County where the city of Gillette has developed a municipal well field, and at selected other places where municipal supplies are withdrawn, such as the town of Sundance in Crook County. There are two places where monitoring for general resource information needs to continue: (1) Northwestern Crook County, where previous hydrologic investigations of the Madison were concentrated, and (2) in eastern Niobrara County where a large industrial well field was considered in the late 1970's but not developed.

Most of the water withdrawn from the lower Mesozoic rock unit is used for oil-field waterflooding (fig. 6). The principal aquifer used is the Lakota Formation in the Inyan Kara Group. At least one observation well is needed in central Weston County to monitor water levels in response to the oil-field waterflooding. 


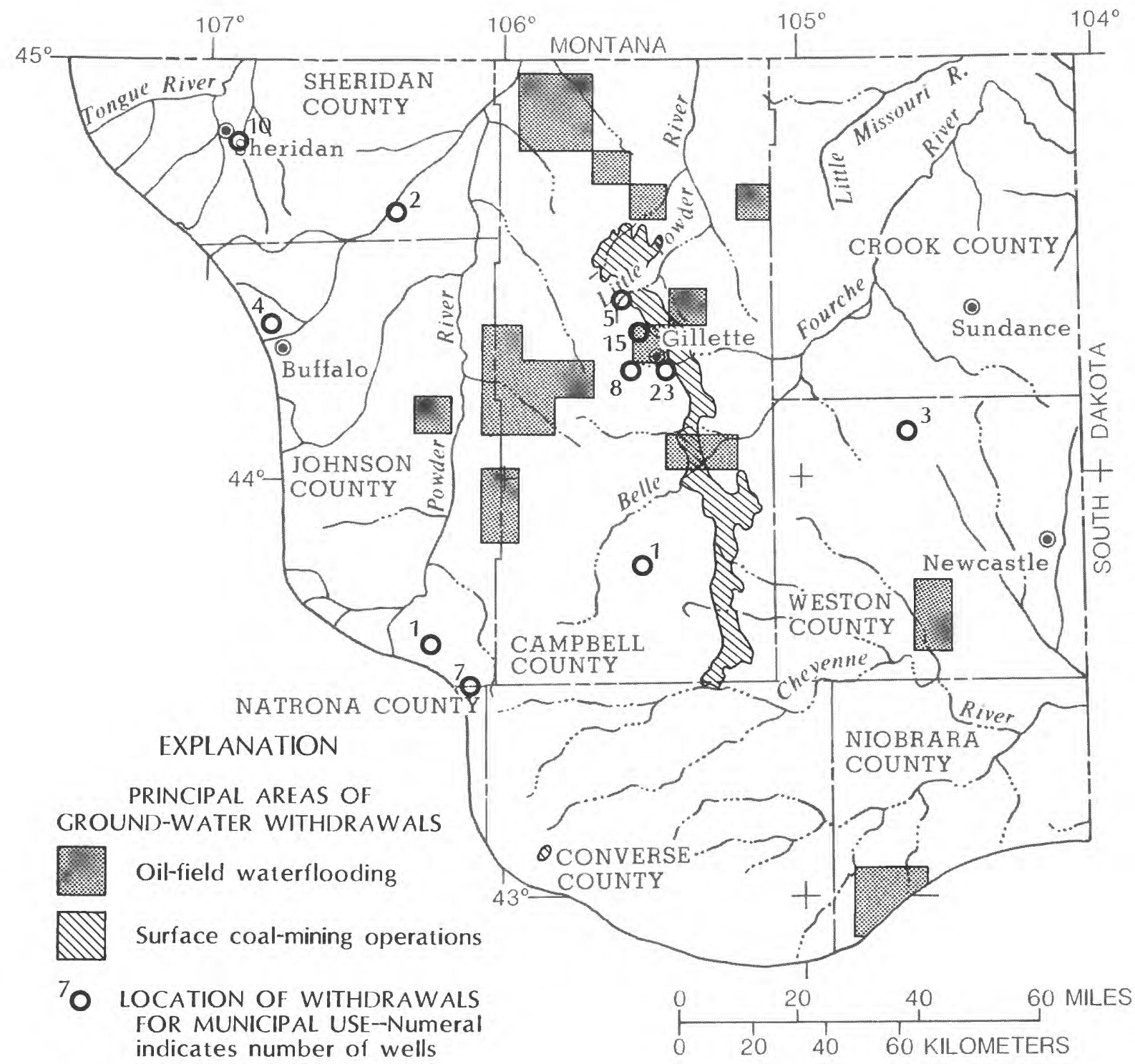

Figure 8.--Location of ground-water withdrawals from the Tertiary rock unit for oil-field waterflooding, surface coal-mining operations, and municipal use. (Data from Wyoming Oil and Gas Conservation Commission, 1982; Feathers and others, 1981; and Hausel and others, 1979.)

Most of the water withdrawn from the Fox Hills Sandstone, the principal aquifer in the upper Mesozoic rock unit, is used for oil-field waterflooding; however, four wells at Gillette and six wells near Moorecroft supply water for municipal use (fig. 7). In order to monitor water levels in the Fox Hills Sandstone, observation wells are needed in eastern and northern Campbell County and in southwestern Crook County, possibly near the group of wells that supply water to the town of Moorecroft.

The resource-development and water-use activities affecting water in the Tertiary rock unit are located mainly in Campbell County (fig. 8). In addition to extensive oil-field waterflooding and a large number of municipal and public-supply wells, ground water is affected by production of coal from 16 surface mines (Martin and others, 1988). The mines commonly destroy shallow aquifers in overburden and coal beds; many backfilled areas become aquifers after mining is completed. 
Observation wells completed in the Lance and Fort Union Formations of the Tertiary rock unit are needed in western and northern Campbell County to monitor the effects of oil-field waterflooding. In addition, several wells are needed to monitor water levels in the principal aquifers in the vicinity of Gillette--particularly in the Lance, Fort Union, and Wasatch Formations. Most of the current (1986) withdrawals are from the Fort Union Formation. The Wasatch Formation was the principal source of water for Gillette until 1982, when the city switched to new wells completed in the Paleozoic rock unit in southwestern Crook County (fig. 5). Because the city no longer uses water from the Wasatch Formation, recovery of water levels in the Wasatch needs to be monitored. Water levels also need to be monitored in the vicinity of the group of public-supply wells completed in the Lance Formation in northeastern Natrona County, and the group of municipal-supply wells completed in the Fort Union Formation near Sheridan (fig. 8).

Observation wells are not needed at present (1986) in the Tertiary rock unit in the vicinity of the surface coal mines in Campbell and northern Converse Counties. Water levels in the upper part of the Tertiary rock unit are monitored by the mining companies in about 1,200 observation wells in and adjacent to 22 mining operations. The wells were installed by the mining companies as required by State and Federal mining laws. The data collected by the individual companies are published collectively each year by the Gillette Area Groundwater Monitoring Organization (1985). The data include water levels in the overburden, in the coal beds, and in some reclaimed backfill areas.

Water quality needs to be monitored in the Tertiary rock unit throughout the area of coal-mining operations shown in figure 8. Ideally, hydrologic monitoring begins before the start of mining operations and continues long after mining operations have been completed. Although general needs for monitoring water quality usually are met by the companies that operate the individual mines, the Geological Survey, Wyoming Department of Environmental Quality, and U.S. Office of Surface Mining are investigating the cummulative effects of mining, as well as the changes in water quality as water passes through the spoil materials used to backfill mined areas.

\section{Existing Network}

Once monitoring needs have been determined, the next step in the process of evaluating a network is to compare those needs with the existing observation-well network. In this step, monitoring deficiencies indicate where additional wells are needed. Wells no longer needed, if any, also need to be identified.

The existing network in the northeastern Wyoming ground-water area during 1986 consisted of 18 observation wells used to monitor water levels (fig. 9). Generally, these observation wells were established in areas where ground water is used in large quantities. Data from observation wells for the most recent 10-year period are published at 2- to 3-year intervals by the Geological Survey in cooperation with the State Engineer.

The observation wells in the current (1986) network are in locations suitable to meet most of the monitoring needs previously discussed. If all needs are to be covered, however, it will be necessary to add wells to the network in particular rock units, as discussed in the remainder of this section.

Thirteen of the existing 18 observation wells are completed in the Paleozoic rock unit (fig. 9). These wells generally meet the previously stated needs for information about the effects of oil-field waterflooding, withdrawals for municipal and public-supplies, and general resource appraisal. Additional wells completed in the Paleozoic rock unit are not needed; in fact, two wells monitoring withdrawals from the Madison Limestone for waterflooding in northeastern Weston County can be discontinued. 


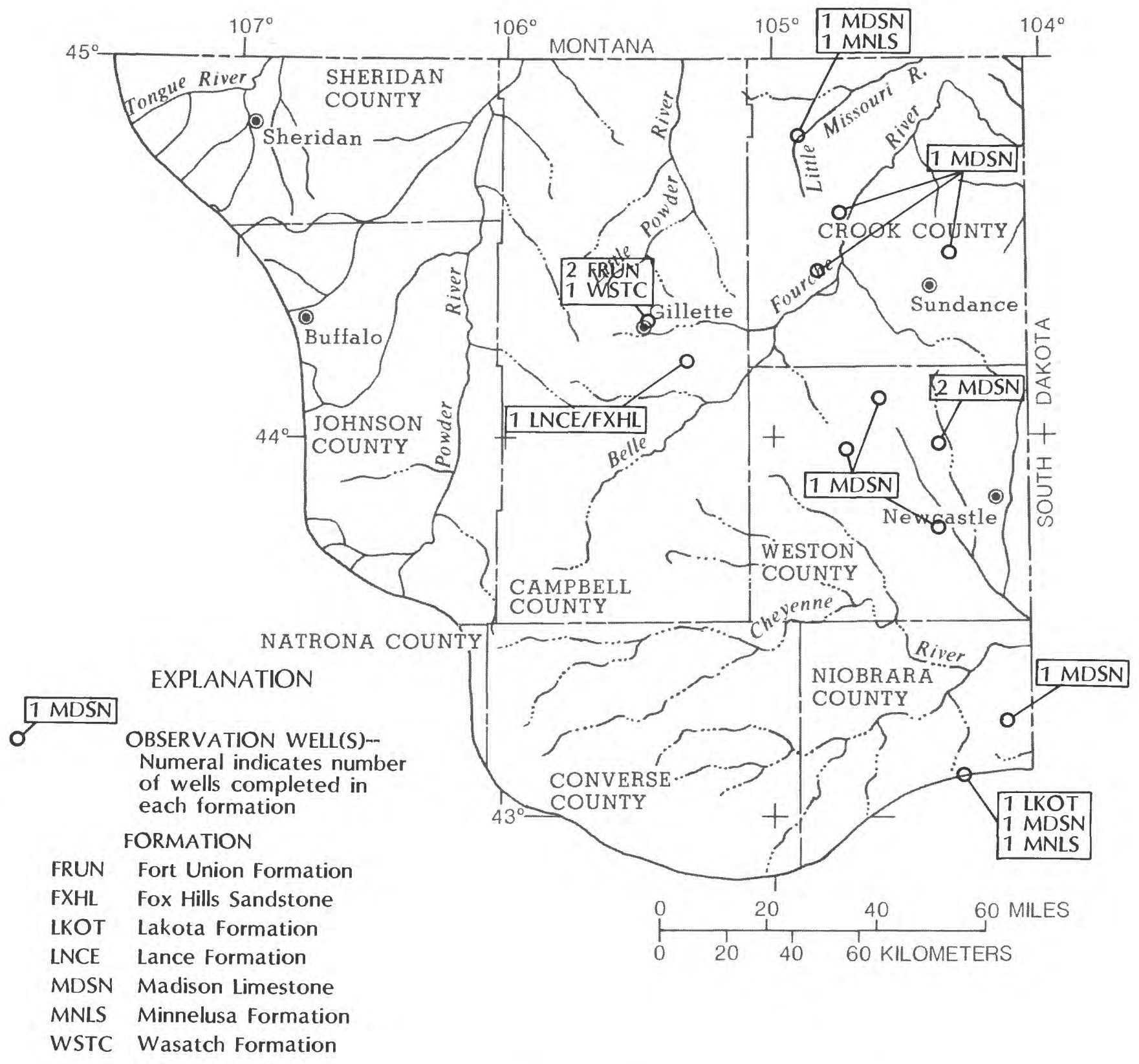

Figure 9.--Location of observation wells in northeastern Wyoming, 1986. Formations being monitored for water-level changes are indicated.

There is only one observation well completed in the lower Mesozoic rock unit; this well is completed in the Lakota Formation in Niobrara County (fig. 9). An additional observation well is needed in central Weston County because of the substantial withdrawals of water from the Lakota for oil-field waterflooding. If the observation well is established in Weston County, the one in Niobrara County can be discontinued after sufficient data have been collected to define the trend of the water level.

Only one well is being used to monitor the water level in the upper Mesozoic rock unit (fig. 9). This well, in Campbell County, is completed in the Fox Hills Sandstone and includes the overlying Lance Formation of the Tertiary rock unit. The well is in a good location to continue monitoring water-level trends. Additional observation wells need to be established in the Fox Hills Sandstone in eastern and northern Campbell County and in southwestern Crook County. 
Three observation wells, all in Campbell County, are being used to monitor water levels in the Tertiary rock unit (fig. 9). Two wells are completed in the Fort Union Formation, and one well is completed in the Wasatch Formation. The two wells in the Fort Union were added to the network in 1985; it may be necessary to replace one of the wells because of inadequate records. Additional observation wells needed to monitor water-level changes in this unit include: One well completed in the Lance Formation near the group of wells used for municipal use in northeastern Natrona County, and one well each completed in the western and northern parts of Campbell County to monitor water levels in the Lance and Fort Union Formations in areas of pumpage for oil-field waterflooding.

The existing (1986) observation-well network in the northeastern Wyoming ground-water area, and suggested modifications to the network, are summarized in the following table:

\begin{tabular}{lcccc}
\hline & \multicolumn{4}{c}{ Number of wells } \\
\cline { 2 - 5 } Rock unit & Existing & Additional & Discontinue & Total \\
\hline Quaternary & 0 & 0 & 0 & 0 \\
Tertiary & 3 & 3 & 1 & 5 \\
Upper Mesozoic & 1 & 3 & 0 & 4 \\
Lower Mesozoic & 1 & 1 & 1 & 1 \\
Marine & 13 & 0 & 2 & 21 \\
\hline Totals & 18 & 7 & 4 & \\
\hline
\end{tabular}

\section{Modification of Network}

There are several ways to establish observation wells; however, the preferred method in Wyoming is to make a site inventory to determine if there are existing wells in the area that would be suitable to monitor water levels. During a site inventory, only wells completed in the aquifer of interest are considered, in contrast with a well inventory, in which all wells are recorded. Sources of information on well location, depth, completion, use, or pumpage include U.S. Geological Survey files, State or county files, or reports from previous ground-water investigations. Any candidate well for the observation-well network needs to be inspected thoroughly before the well is added to the network. The frequency and type of measurement need to be determined for each new well. Whether or not to install a water-level recorder usually depends on anticipated changes in water levels.

\section{Observation-Well Records}

Records for each observation well need to be maintained in a site file that includes:

1. A detailed site-inventory schedule on which all information about the well is recorded, including a sketch showing access route(s) to the well. A modification of the Geological Survey form (fig. 10) is designed so that information can be entered into a computerized record-storage/retrieval system.

2. A photograph of the well for ease of identification. 


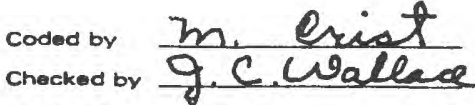

Entered by
U.S. DEPT. OF THE INTERIOR GEOLOGICAL SURVEY

WATER RESOURCES DIVISION

GROUND-WATER SITE SCHEDULE
File Code

Date

$1 / 25 / 85$ Generel Site Data

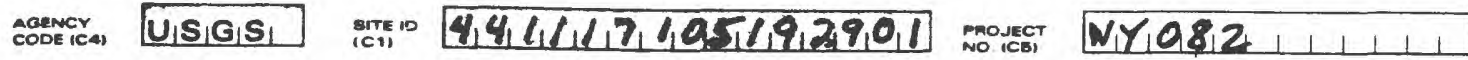

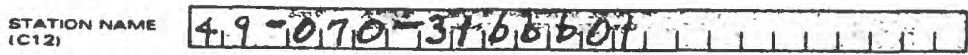

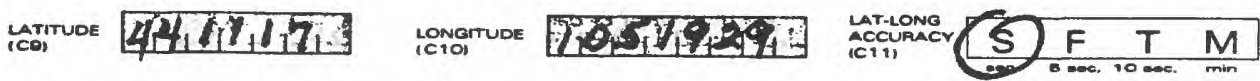

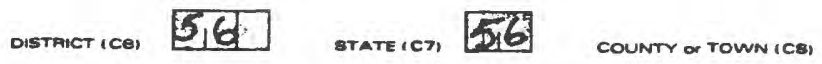

Campbell

005

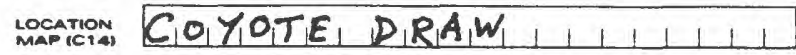

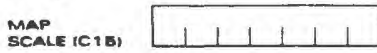

cameneson

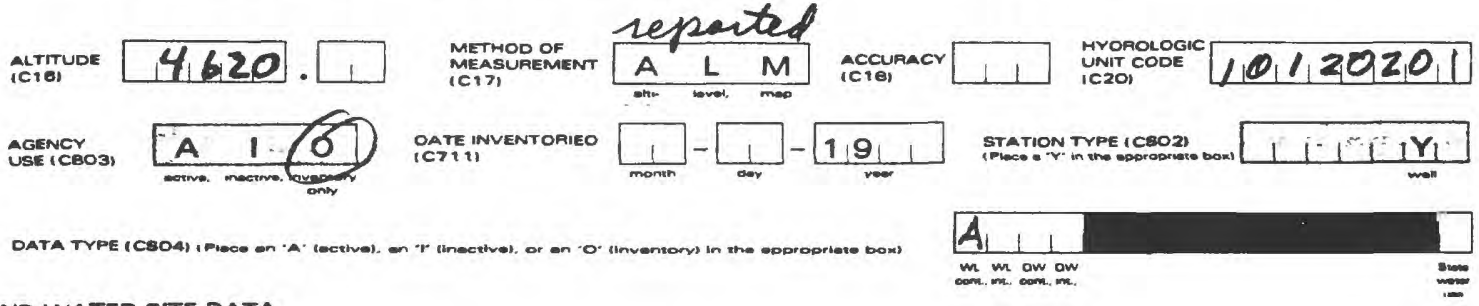

GROUND-WATER SITE DATA

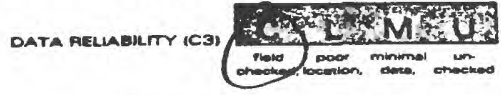

ITE TYPE IC2) C.

DATE OF CONSTRUCTION IC2V)

$0,1-2,8-\frac{1,98,1}{2}$

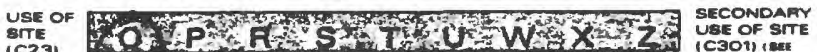

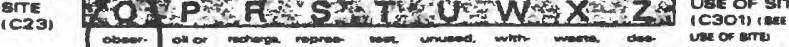

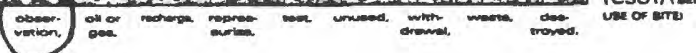

TEATIAar

UBE OF

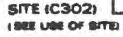

USE OF WATER

\begin{tabular}{|lllllllllllllllllllll}
\hline$A$ & $B$ & $C$ & $D$ & $E$ & $F$ & $H$ & $I$ & $J$ & $K$ & $M$ & $N$ & $P$ & $Q$ & $R$ & $S$ & $T$ & $U$ & $Y$ & $Z$ \\
\hline
\end{tabular} SECONDAFT USE
OF WATEF (C26) OF WATEA ICZ

\begin{tabular}{|lllll}
\hline & $N$ & $C$ & $M$ & $X$ \\
\hline
\end{tabular}

POMARAY $2, \|, L, M C, E$ SECONDAFY

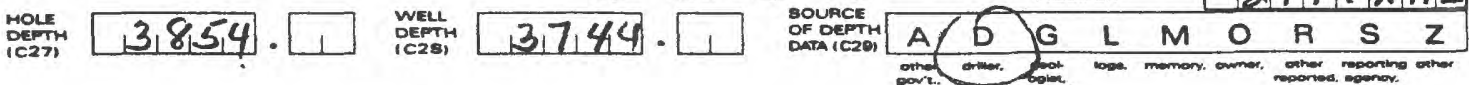

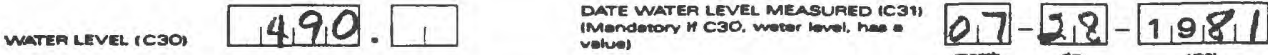

SOUACE OF WATEA-LEVEL DATA ICI3)! \begin{tabular}{|ccccccccc|}
$A$ & $D$ & $G$ & $L$ & $M$ & $O$ & $R$ & $S$ & $Z$ \\
\hline
\end{tabular}

CONSTRUCTION DATA

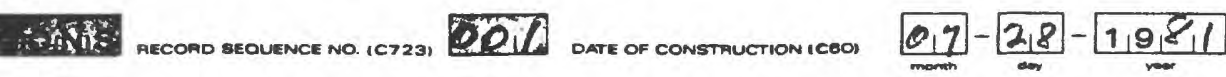

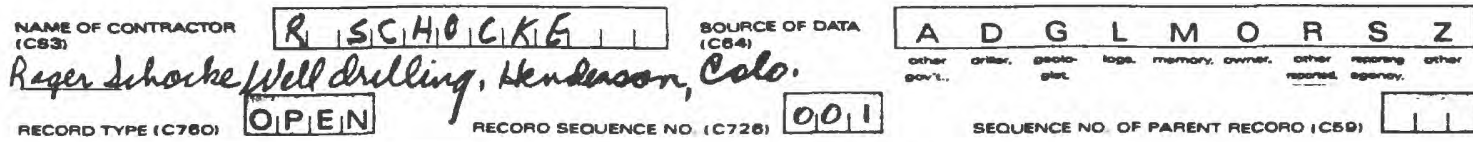

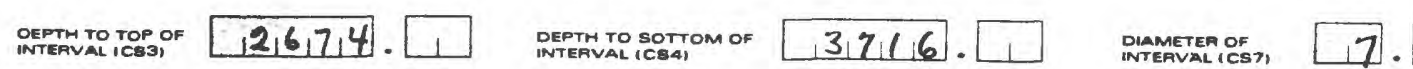

2 MATERIAL TYPE ICSOIS ${ }^{3}$ TYPE OF OPENING S

LENGTH OF OPENING

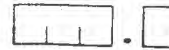

WIDTH OF OPENANG

Figure 10.--Example of site schedule form. 
CONSTRUCTION CASING DATA ( 3 *t: sehown)

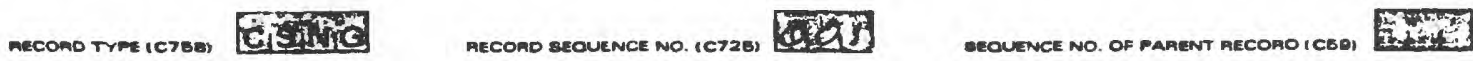

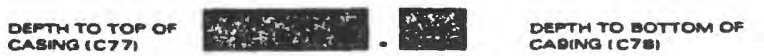
2435

1 casing material (cso)
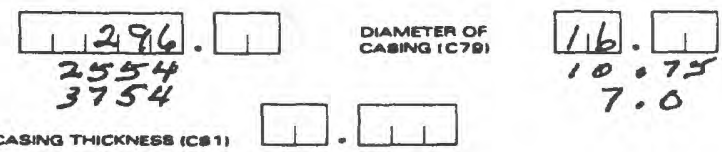

Miscellaneous OWNER DATA

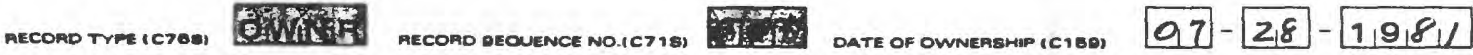

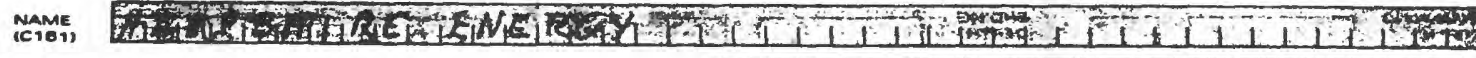
miscelLaNeOUS OTHER ID DATA

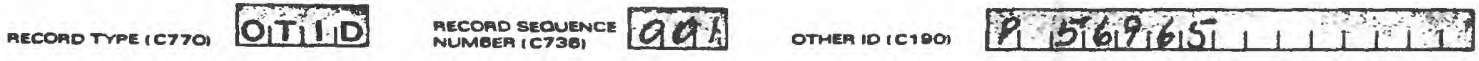

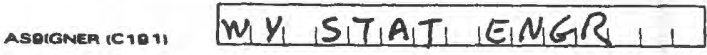

MISCELLANEOUS VISIT DATA

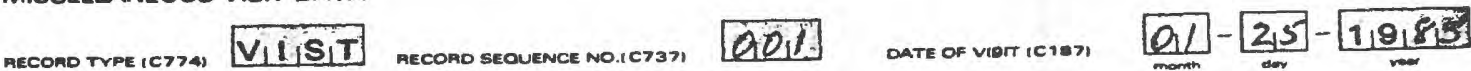

NAME OF MEAEON (C188)

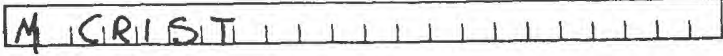

MISCELLANEOUS OW DATA $(3$ sot: shown)

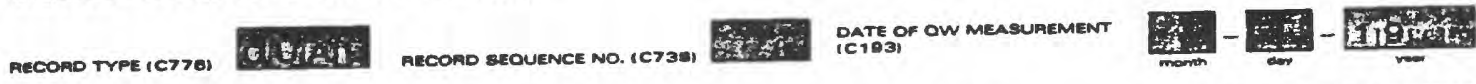

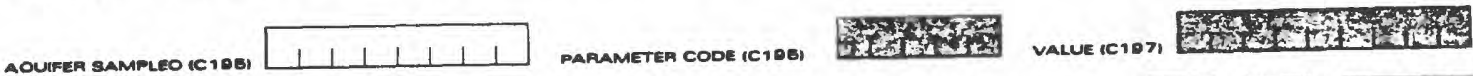

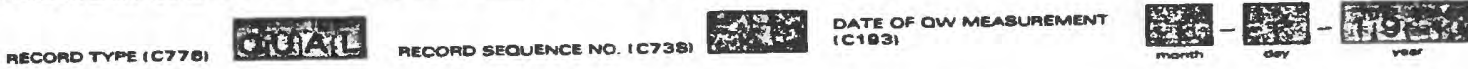

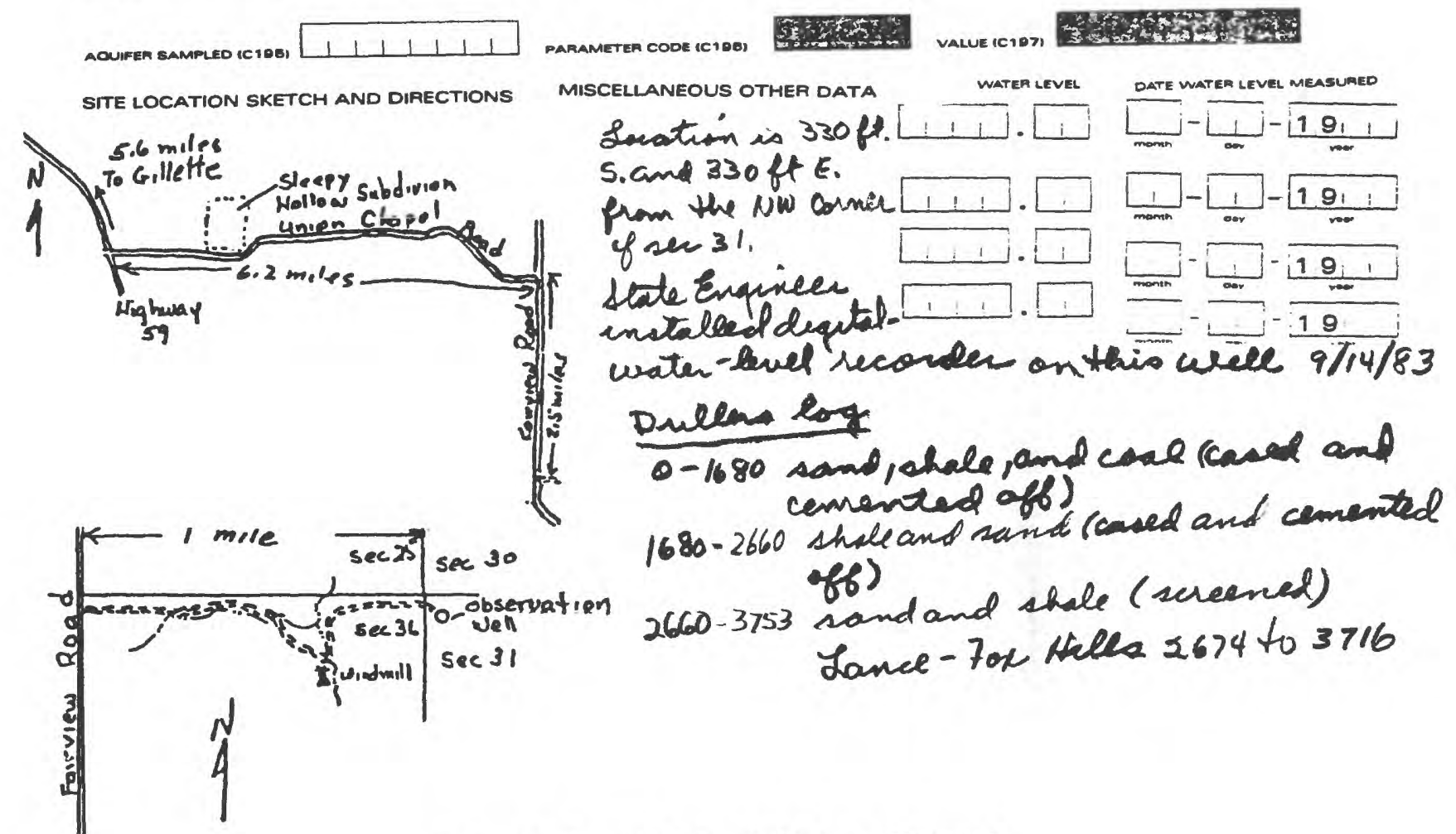

Figure 10.--Example of site schedule form--Continued. 
3. A single-sheet form that summarizes the data collected at the observation well. Useful for network evaluation, this form (fig. 11) includes:
a. History of observations (period of record).
b. Type of data collected (water levels, water quality, or other).
c. A statement giving the reason for measurement (purpose of well).
d. Measurement frequencies and the period of record for each.
e. Discussion of trends or analysis of the data, or both.
f. Remarks.--Any other information pertinent to the well.

4. The original water-level data form listing measurements of water levels (fig. 12). This form is kept in a binder or in a separate folder in the site file. The water levels are entered into the U.S. Geological Survey ground-water site information (GWSI) system after every site visit. When a water-level data form is completed, it is placed in the historical site file.

5. Water-level hydrograph (fig. 13).

6. Any available water-quality data.

\section{Network Review}

Data from the observation wells need to be reviewed periodically to determine if the monitoring objectives are being achieved. This review has been done by the Geological Survey and the State Engineer in recent years. Observation wells that have fulfilled their purpose or those that have failed to do so can be discontinued. Changes in location or magnitude of water-development or water-use activities that could affect ground water may indicate a need for observation wells at new locations.

\section{REPORTING GROUND-WATER DATA}

The Geological Survey has measured ground-water levels in Wyoming since 1940, mainly in cooperation with the Wyoming State Engineer. From time to time, other agencies at the local, State, or Federal level have participated in the program. Water-level data for 1940-85 have been published in 10 reports compiled by the U.S. Geological Survey: Ringen $(1973,1974)$; Ballance and Freudenthal (1975, 1976, 1977); Stevens (1978); Ragsdale (1982); Ragsdale and Oberender (1985); Kennedy and Oberender (1987). The earliest of these reports consisted only of tabular data; in the more recent reports, water-level hydrographs were used as the main format for presenting the data.

In this section, a different format is described for presenting hydrologic data collected at observation wells. Data for the 18 wells in the northeastern Wyoming ground-water area are presented by county. For each county, hydrographs are arranged adjacent to a map showing the location of the wells. A brief narrative is included to provide information about the data collected. The narrative includes such things as: changes in water levels, water quality, or ground-water use; possible changes in the hydrologic conditions that might affect the data; and other pertinent information.

\section{Campbell County}

Four observation wells were monitored in Campbell County during 1986 (fig. 14), including the two wells completed in the Fort Union Formation at Gillette that were added to the observation-well network in 1985. 
OBSERVATION-WELL SUMMARY

AREA Bander Rive brain court y Camp hall WELL NUMBER $49-70-3 / B B B$ SITE ID No. 44117105192901 TYPE OF DATA COLLECTED Water level BEGAN $9-14-83$ ENDED JUSTIFICATION FOR MEASUREMENT (Include types of information desired) above water -level flustusans in the Lance - Tux bills became of large jumpage from MEASUREMENT FREQUENCY: then es from $9-14-83$ to from to from to.

DATA ANALYSIS 8.5.86 Declining trend pubacly reveler of pumping for oil-field evaterflesding

REMARRS (date slug tested, equipment installed or changed, conditions near

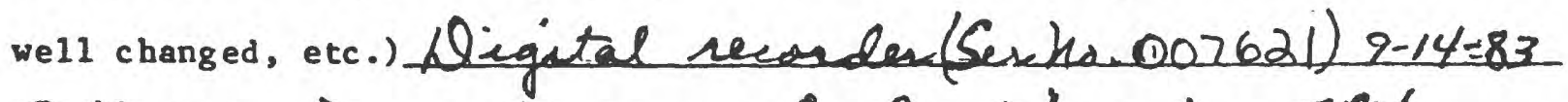
All equipment awned by Wyoming state En greer

WELL STATUS REVIEWED:
Date $8-5-86$

Date by mon. Chit by

Date by

Date by

Figure 11.--Example of observation-well summary form.

20 

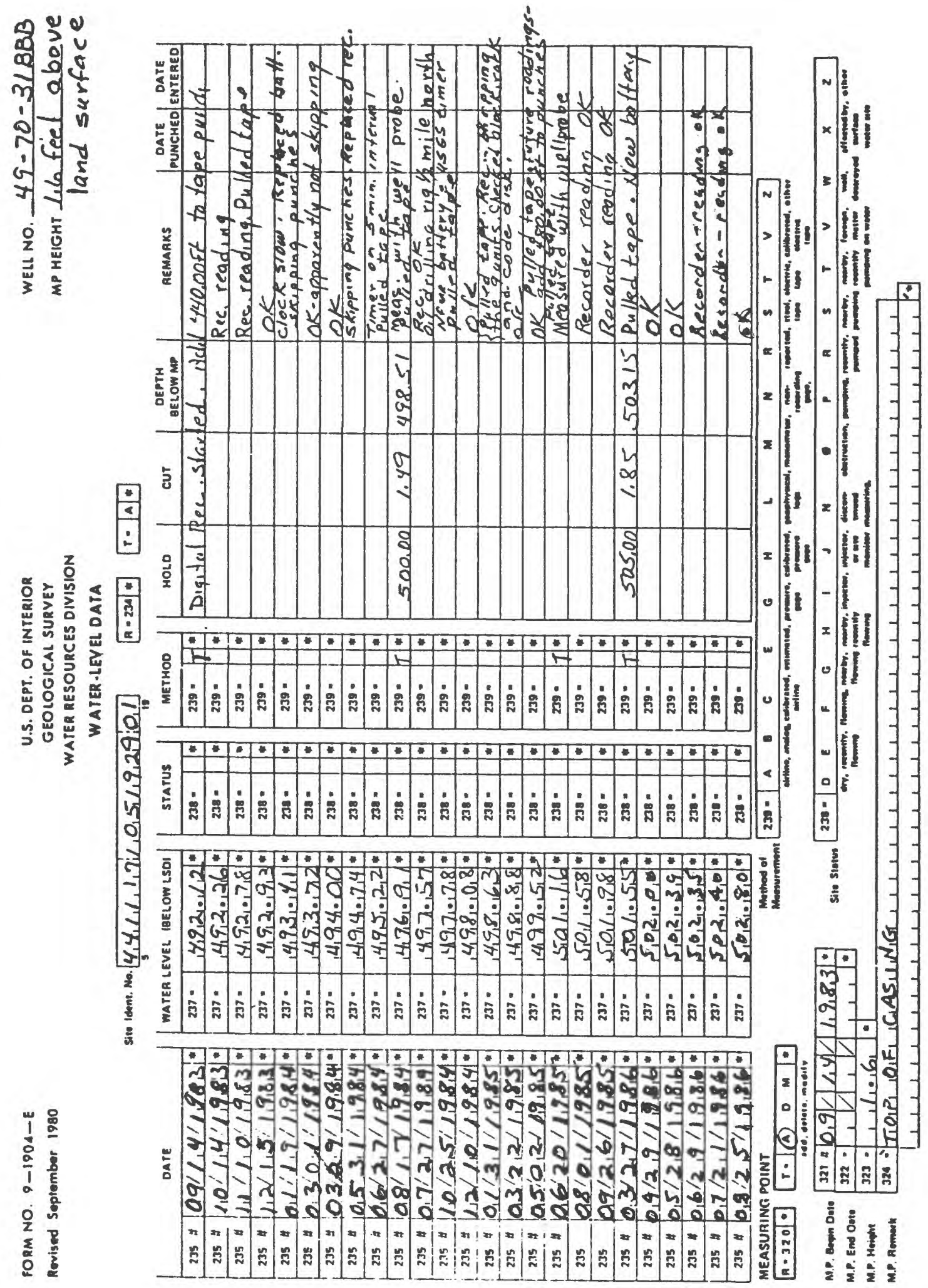


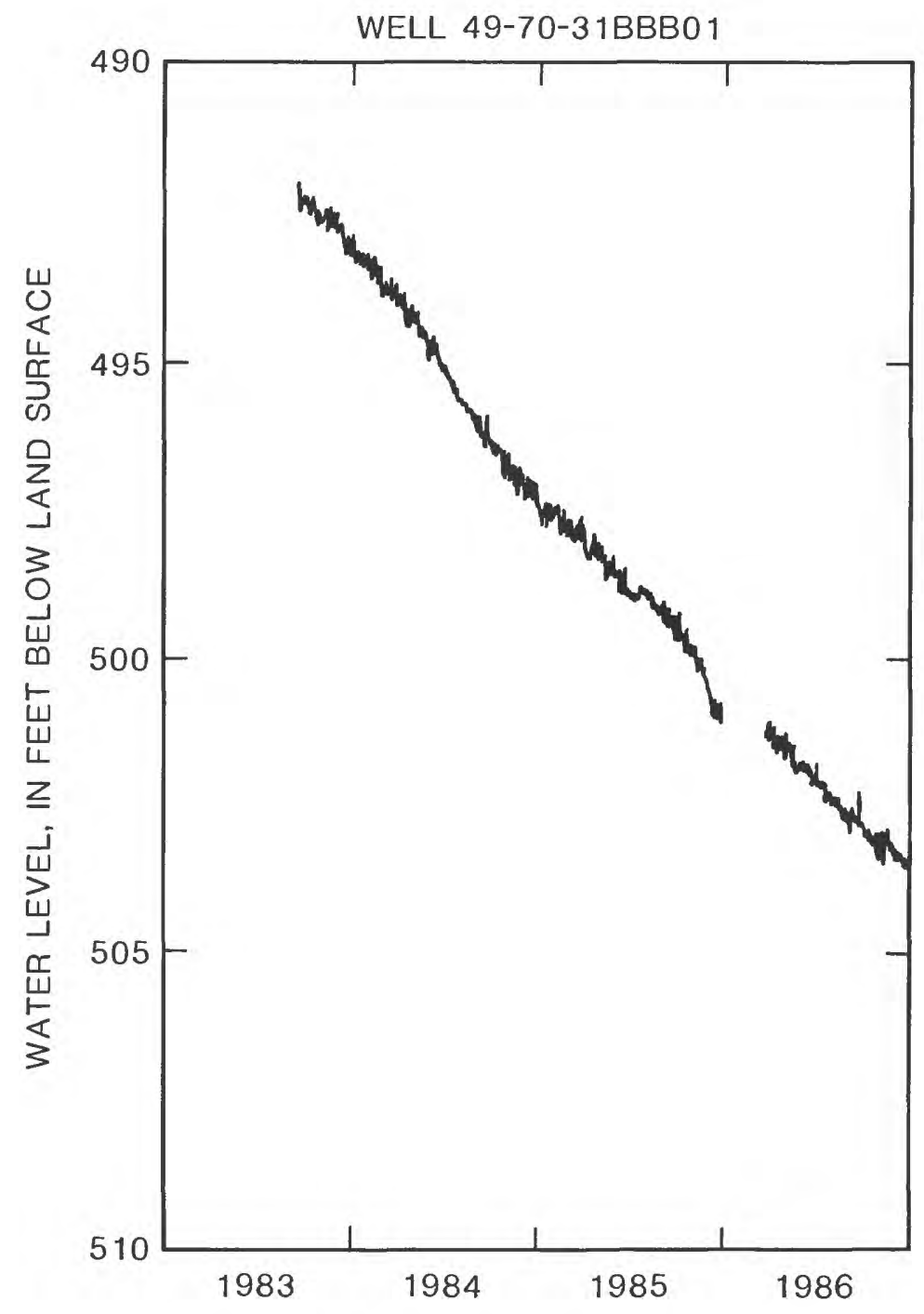

Figure 13.--Example of water-level hydrograph.

The water level has been declining steadily in well 49-70-31BBB01, located southeast of Gillette, since measurements were started in September 1983. The well is completed in both the Lance Formation and the Fox Hills Sandstone. The Fox Hills Sandstone is the principal source of water for oil-field waterflooding in Campbell County. As shown previously (fig. 7), pumpage from the upper Mesozoic rock unit for oil-field waterflooding is quite widespread in the county.

Water levels in the three observation wells at Gillette may be affected by municipal pumpage. A large water-level decline in the Fort Union Formation is indicated in well 50-72-22DBA01. In this well, located at the east side of Gillette, dirty casing has prevented optimum operation of the digital water- level recorder since October 1985 . The well needs to be cleaned to obtain reliable water-level data using the digital recorder.

A digital water-level recorder was installed in December 1985 at well 50-72-20CAB01. This well is located on the west side of Gillette and has not been pumped for several years. More data are needed to determine if the water-level rise represents a long-term trend or can be attributed to seasonal fluctuation. 


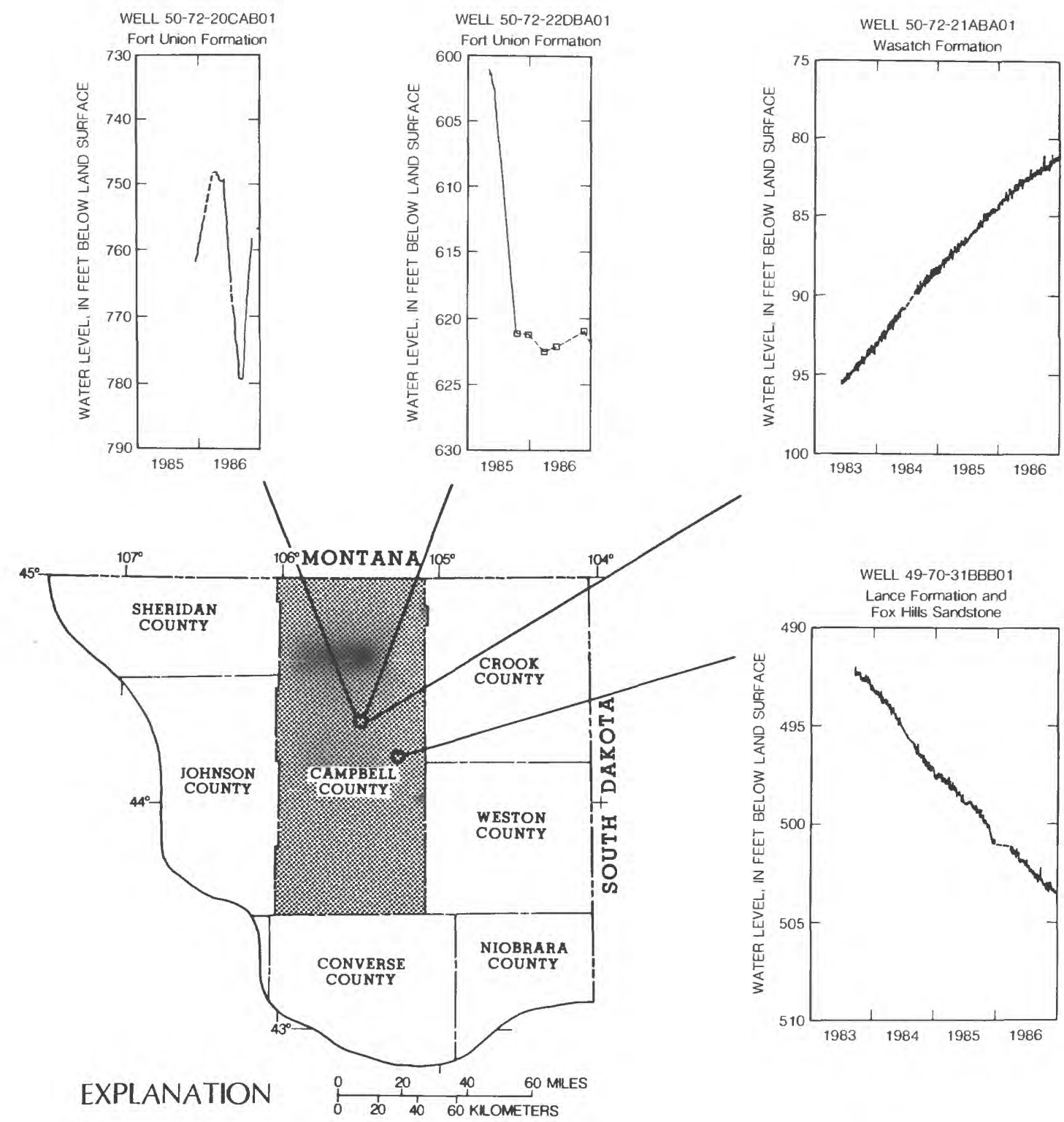

- OBSERVATION WELL(S)

Figure 14.--Location map and hydrographs of water levels in wells in Campbell County. Dashed lines indicate periods of no water-level data.

The water level in well 50-72-21ABA01, completed in the Wasatch Formation, has been rising since 1983. The City of Gillette stopped pumping water from the Wasatch Formation for municipal use in 1982 , so the record at this well probably represents recovery of the aquifer after cessation of pumping.

\section{Crook County}

Five observation wells are used to monitor water levels in Crook County (fig. 15). The Madison Limestone is the principal source of ground water in the county. Water-level fluctuations in well 51 66-6DCD01, located in the southwestern part of the county, result from pumping of nearby wells for 

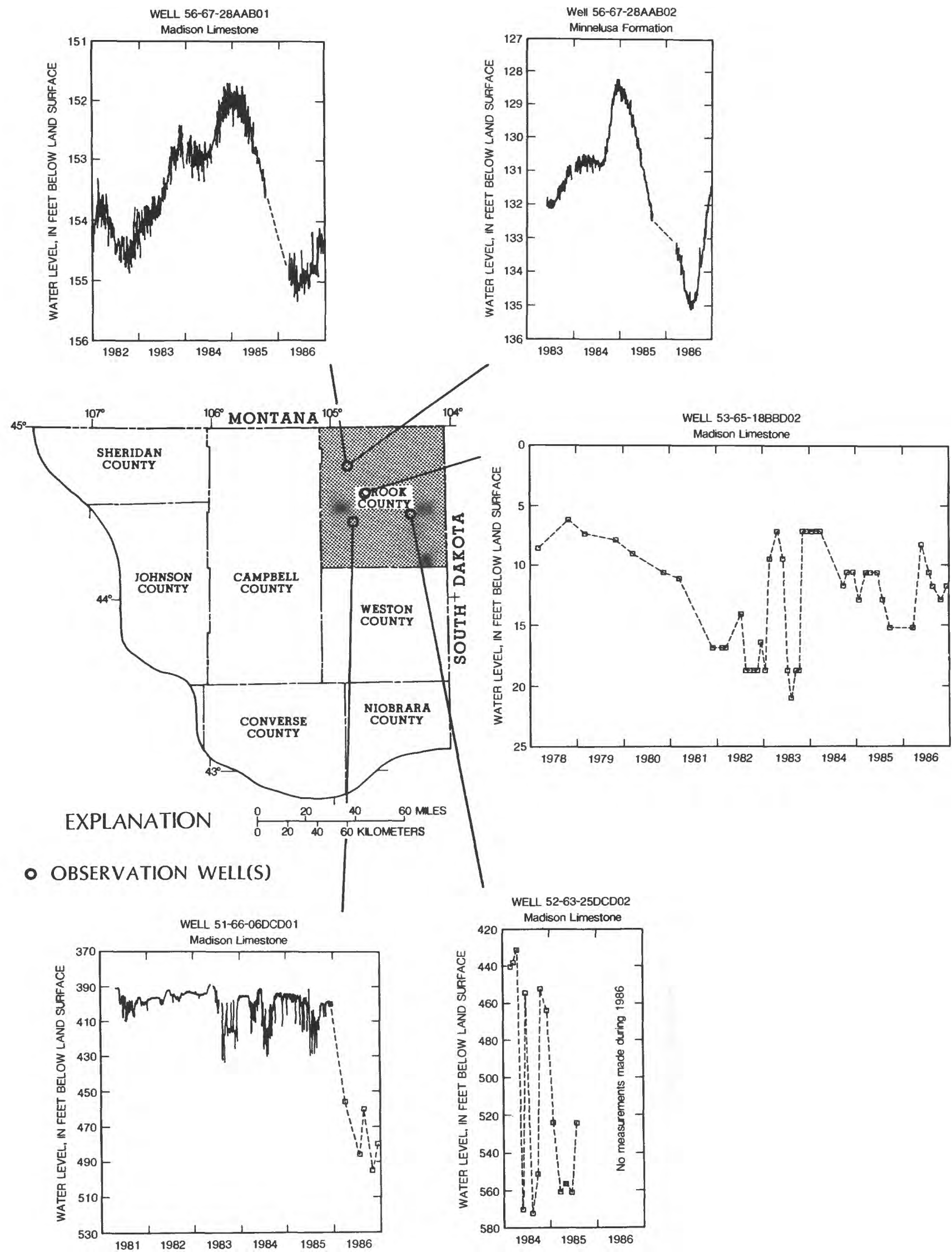

Figure 15.--Location map and hydrographs of water levels in wells in Crook County. Dashed lines indicated periods of no water-level data. 
municipal supplies in Gillette. Water-level fluctuations in well 56-67-28AAB01, located in the northwestern part of the county, probably are representative of natural fluctuations of water levels in the Madison Limestone. The city of Sundance withdraws water from wells completed in the Madison (Pahasapa) Limestone. These withdrawals cause fluctuations of the water level in the Madison Limestone at well 52-63-25DCD02.

Observation well 53-65-18BBD02, completed in the Madison Limestone at Devils Tower (the Nation's first National Monument), is the sole source of water for the visitor center, campground, and other visitor facilities. The water-level fluctuations correlate with visitor use of the park. The flat parts of the hydrograph during 1981-85 are due to erroneous air-line readings at the well head, caused by recurring failure of a check valve.

\section{Niobrara County}

Four observation wells were monitored in Niobrara County during 1986 (fig. 16). The water level in well 36-62-28AB01, completed in the Madison Limestone, has declined about 4 feet between 1980 and 1986. In the same area, the water level in the Minnelusa Formation (well 36-62-28BBD01) remained fairly stable between 1983 and 1986. The water level in well 36-62-28AB02 in the Lakota Formation has declined about 18 feet between 1974 and 1986. This decline may be the result of oil and water production from the Lakota Formation. About 12 miles north of these wells, the water level in the Madison Limestone (well 38-61-35DCA01) rose about 10 feet between 1983 and 1986.

\section{Weston County}

Five observation wells were used to monitor water levels in Weston County during 1986 (fig. 17). Only the water level in well 46-63-15ADD01 shows a consistent declining trend. Water flows at the land surface from this well and from well 46-63-10CDA01. Because water levels in these wells are above the land surface, the hydrographs indicate the height above land surface to which the water would rise. A digital water-level recorder is used at well 46-66-25DBB01; periodic measurements are made manually at the other wells.

\section{SUMMARY}

A logical sequence of eight steps was developed for evaluating and modifying the existing long-term observation-well network in any part of Wyoming. The first step, which needed to be done only once, was to delineate nine ground-water areas in nonmountainous parts of Wyoming, based on major structural features. The ground-water system within each area generally can be considered to be independent of the ground-water system in other areas. Northeastern Wyoming is the first of the nine areas to be evaluated using these procedures.

In the second step, also done only once, the stratigraphic units of Wyoming were grouped into five rock units based on age and similarity of depositional environments and water-yielding properties. These units, from oldest to youngest, are: (1) Paleozoic rock unit, (2) lower Mesozoic rock unit, (3) upper Mesozoic rock unit, (4) Tertiary rock unit, and (5) Quaternary rock unit. This grouping is particularly useful where the density of observation wells is as sparse as it is in Wyoming.

The six remaining steps are applied to a selected ground-water area as often as necessary: (step 3) Summarize resource-development and water-use activities that could effect ground water; (step 4) determine needs for monitoring, based on step 3; (step 5) compare needs (from step 4) with the existing observation-well network to determine changes in the network; (step 6) identify and visit wells that can be added to the network to fulfill monitoring needs; (step 7) set up a record file for each observation well; and (step 8) review the network periodically. 

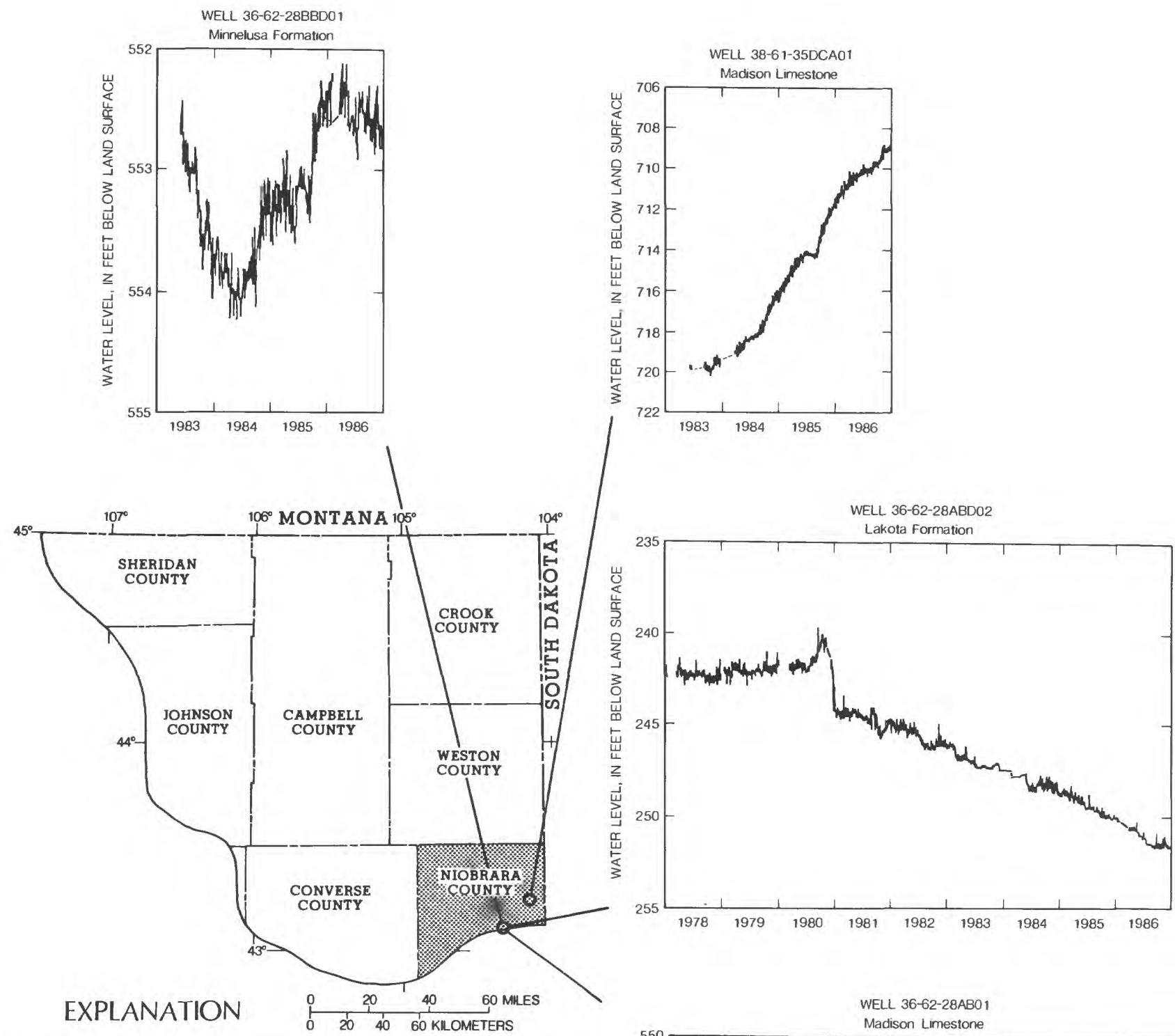

- OBSERVATION WELL(S)

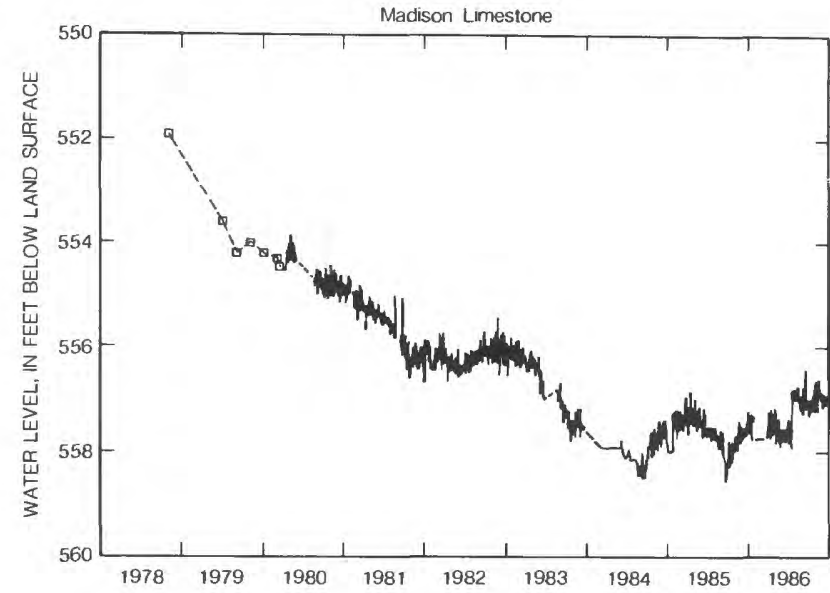

Figure 16.--Location map and hydrographs of water levels in wells in Niobrara County. Dashed lines indicate no water-level data. 


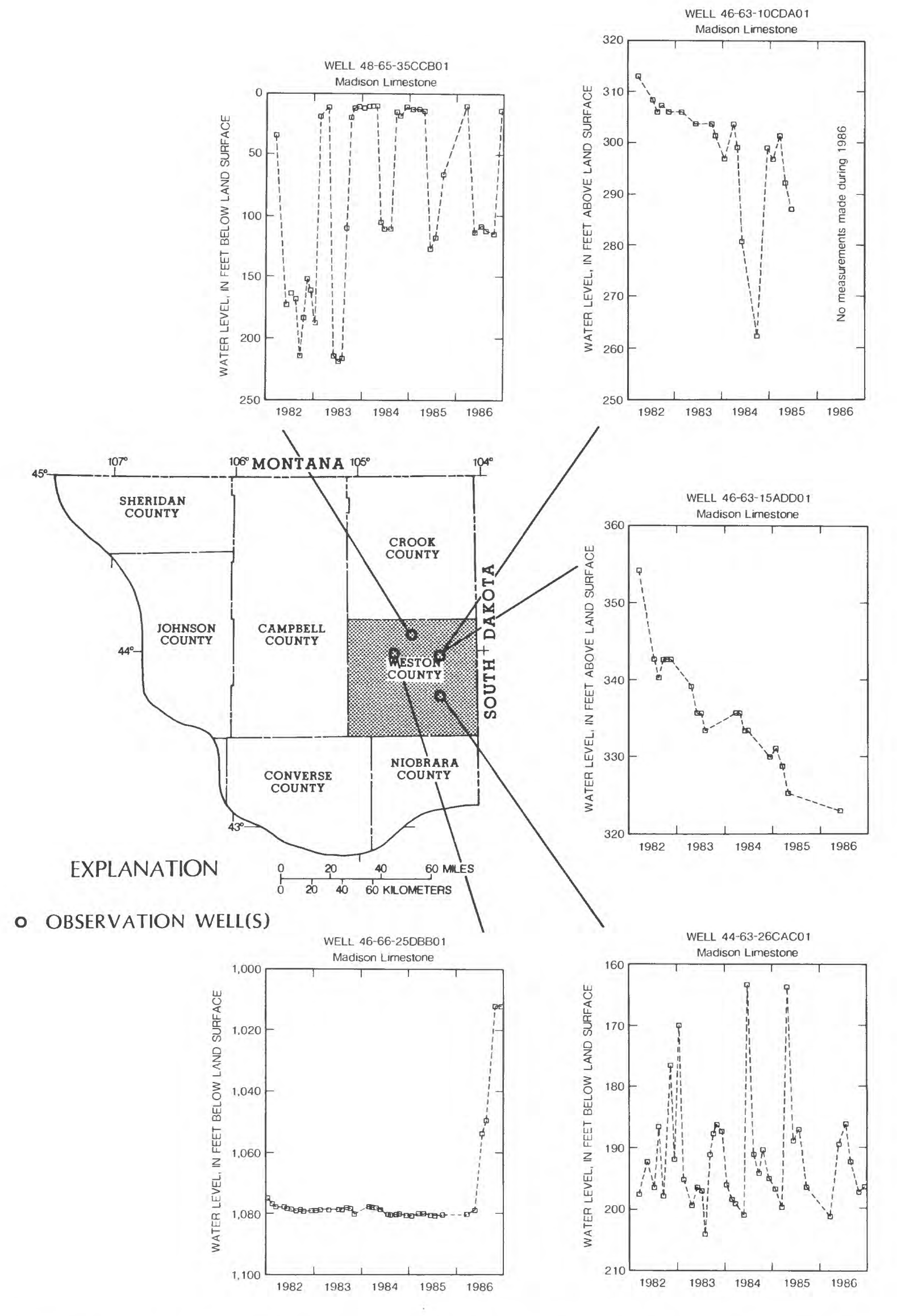

Figure 17.--Location map and hydrographs of water levels in wells in Weston County. Dashed lines indicate periods of no water-level data. 
The activities most likely to affect ground-water quantity or quality in northeastern Wyoming were grouped into three categories: (1) Agricultural and rural-domestic use, (2) use for oil and gas production and for coal and uranium mining, and (3) use for municipal and other public supplies. As a result of the evaluation of the existing (1986) network, the following modifications to the network could be made: (1) Monitoring of two wells completed in the Paleozoic rock unit may be discontinued; (2) one well completed in the lower Mesozoic rock unit needs to be added, and monitoring of a second well may be discontinued; (3) three additional wells are needed in the upper Mesozoic rock unit; and (4) three additional wells completed in the Tertiary rock unit need to be added and monitoring of one well may be discontinued. Monitoring of the Quaternary rock unit is not needed. The net change would be an increase from 18 to 21 wells in the observation-well network in northeastern Wyoming.

Water-level data from the 18 observation wells in northeastern Wyoming are presented in a format somewhat different from that used in previous data reports for Wyoming. For each county, hydrographs of water levels are arranged adjacent to a map showing the location of the wells. An accompanying narrative includes discussion of changes in water levels, changes in water use, possible changes in hydrologic conditions, or other information pertinent to the records obtained.

As of 1985, substantial water-level declines were recorded in one well completed in the Fort Union Formation of Paleocene age near Gillette, in one well completed in the Lance Formation and Fox Hills Sandstone of Late Cretaceous age near Gillette, and in one well completed in the Lakota Formation of Early Cretaceous age in northern Niobrara County. Substantial water-level rises were recorded in one well completed in the Wasatch Formation of Eocene age at Gillette and in one well completed in the Madison Limestone of Mississippian age in northern Niobrara County.

\section{REFERENCES CITED}

Ballance, W.C., and Freudenthal, P.B., 1975, Ground-water levels in Wyoming, 1974: U.S. Geological Survey Open-File Report, 186 p.

1976, Ground-water levels in Wyoming, 1975: U.S. Geological Survey Open-File Report 76-598, $170 \mathrm{p}$.

1977, Ground-water levels in Wyoming, 1976: U.S. Geological Survey Open-File Report 77-686, $187 \mathrm{p}$.

Crist, M.A., and Lowry, M.E., 1972, Ground-water resources of Natrona County, Wyoming: U.S. Geological Survey Water-Supply Paper 1897, 92 p.

Feathers, F.P., Libra, Robert, and Stephenson, T.R., 1981, Occurrence and characteristics of ground water in the Powder River basin, Wyoming: Laramie, University of Wyoming Water Resources Research Institute report to U.S. Environmental Protection Agency, vol. I-A, 171 p.

Flores, R.M., and Ethridge, F.G., 1985, Evolution of intermontane fluvial systems of Tertiary Powder River basin, Montana and Wyoming, in Flores, R.M., and Kaplan, S.S., eds., Cenozoic paleogeography of the west-central United States: Denver, Rocky Mountain Section, Society of Economic Paleontologists and Mineralogists, Rocky Mountain Paleogeography Symposium, 3d, p. 107-126.

Gillette Area Groundwater Monitoring Organization, 1985, Annual report: Gillette, Wyo., Thunder Basin Coal Company, unpaged [published annually since 1983].

Hausel, D.W., Glass, G.B., Lageson, D.R., Ver Ploeg, A.J., and Debruin, R.H., compilers, 1979, Wyoming mines and minerals: Laramie, The Geological Survey of Wyoming, scale 1:500,000. 
Hodson, W.G., Pearl, R.H., and Druse, S.A., 1973 [1974], Water resources of the Powder River basin and adjacent areas, northeastern Wyoming: U.S. Geological Survey Hydrologic Investigations Atlas HA-465, scale 1:250,000, 4 sheets.

Kennedy, H.I., and Oberender, C.B., 1987, Ground-water levels in Wyoming, 1976 through 1985: U.S. Geological Survey Open-File Report 87-456, 122 p.

Love, J.D., 1961, Definition of Green River, Great Divide and Washakie study areas, southwestern Wyoming: American Association of Petroleum Geologists Bulletin, v. 45, no. 10, p. 1749-1755.

Love, J.D., Christianson, A.C., and Ver Ploeg, A.J., compilers, 1987, First draft of proposed stratigraphic nomenclature chart for the State of Wyoming: Laramie, The Geological Survey of Wyoming, 1 sheet.

Lowry, M.E., Wilson, J.F., Jr., and others, 1986 [1987], Hydrology of area 50, Northern Great Plains and Rocky Mountain Coal Provinces, Wyoming and Montana: U.S. Geological Survey WaterResources Investigations Open-File Report 83-545, 137 p.

Martin, L.M., Naftz, D.L., Lowham, H.W., and Rankl, J.G., 1988, Cumulative hydrologic impacts of surface coal mining in the eastern Powder River structural basin, northeastern Wyoming: U.S. Geological Survey Water- Resources Investigations Report 88-4046, 201 p.

Osborne, H.C., Thomas, C.E., Armstrong, J.F., Crain, L.L., Mahoney, C.F., Kelton, F.C., LaFayette, Bill, and Smith, J.E., 1962, Water-injection pressure maintenance and waterflood processes, in Frick, T.C., and Taylor, R.W., eds., Petroleum production handbook, vol. II--Reservoir engineering: New York, McGraw-Hill, chap. 41, 71 p.

Ragsdale, J.O., 1982, Ground-water levels in Wyoming, 1971 through part of 1980: U.S. Geological Survey Open-File Report 82-859, 200 p.

Ragsdale, J.O., and Oberender, C.B., 1985, Ground-water levels in Wyoming, 1974 through 1983: U.S. Geological Survey Open-File Report 85-403, 194 p.

Ringen, B.H., 1973, Records of ground-water levels in Wyoming, 1940-1971: Cheyenne, State Engineer's Office, Wyoming Water Planning Program Report, no. 13, 479 p.

_1974, Ground-water levels in Wyoming, 1972-73: Cheyenne, State Engineer's Office, Wyoming Water Planning Program Report, no. 13, supplement, no. 1, 158 p.

Stevens, M.D., 1978, Ground-water levels in Wyoming, 1977: U.S. Geological Survey Open-File Report 78-605, $203 \mathrm{p}$.

Wyoming Oil and Gas Conservation Commission, 1982, Wyoming oil and gas statistics 1982: Casper, part 2,19 p., and part 3,11 p. 